\title{
Effects of soil nutrient availability and ozone on container-grown Japanese larch seedlings and role of soil microbes
}

\author{
Evgenios Agathokleous ${ }^{1,2} \cdot$ Mitsutoshi Kitao $^{2} \cdot$ Masabumi Komatsu $^{3} \cdot$ Yutaka Tamai $^{4} \cdot$ \\ Hideyuki Saito $^{4} \cdot$ Hisanori Harayama $^{2}$ - Akira Uemura $^{5} \cdot$ Hiroyuki Tobita $^{5}$. \\ Takayoshi Koike ${ }^{4}$
}

Received: 17 April 2019 / Accepted: 1 July 2019 / Published online: 18 October 2019

(C) The Author(s) 2019

\begin{abstract}
The interactive effects of ozone, soil nutrient availability and root microorganisms on physiological, growth, and productivity traits were studied for the first time for Japanese larch (Larix kaempferi) seedlings grown in containers over a growing season, using a free air ozoneconcentration enrichment exposure system. High nutrient availability altered leaf and root nutrient dynamics and enhanced plant growth; however, it also enhanced seedling susceptibility to damping-off disease compared to low nutrient availability. Negative effects of elevated ozone, as compared with ambient ozone, on leaf gas exchange and plant stem form were neither offset nor exacerbated by soil nutrient availability and root colonizers. Such negative effects suggest that elevated ozone may have implications for ecological health even when plant vigor is limited by factors
\end{abstract}

Project funding: The Project was fully funded by JSPS KAKENHI Grant Number JP17F17102.

The online version is available at http://www.springerlink.com

Corresponding editor: Zhu Hong.

Electronic supplementary material The online version of this article (https://doi.org/10.1007/s11676-019-01056-y) contains supplementary material, which is available to authorized users.

Evgenios Agathokleous

evgenios@ nuist.edu.cn

1 Institute of Ecology, Key Laboratory of Agrometeorology of Jiangsu Province, School of Applied Meteorology, Nanjing University of Information Science and Technology (NUIST), Nanjing 210044, Jiangsu, People's Republic of China

2 Hokkaido Research Center, Forestry and Forest Products Research Institute (FFPRI), Forest Research and Management Organization, 7 Hitsujigaoka, Sapporo, Hokkaido 062-8516, Japan other than ozone. Inoculation of roots with ectomycorrhizae had negligible influence on the effects of either soil nutrient availability or ozone. However, this lack of effect may be upon impeded formation of complete mycorrhizal root tips due to factors other than the manipulated variables. B and $\mathrm{Na}$ appeared to have an important role in stress responses, so further studies to examine their link with physiological mechanisms as a function of time. This study provides an important perspective for designing forestry practices to enhance seedling health.

Keywords Ectomycorrhizae $\cdot$ Fertilizer $\cdot$ Oxidative stress $\cdot$ Plant-fungi interaction

\section{Introduction}

The degraded quality of the atmospheric environment seen over the last decades is in part due to the increases in the levels of ground-level ozone $\left(\mathrm{O}_{3}\right)$ (Akimoto 2003; Akimoto et al. 2015; Lefohn et al. 2018; Nair et al. 2018). Local and regional regulations has helped decrease $\mathrm{O}_{3}$ levels in parts of the world (Sicard et al. 2013) and the level of air pollutants that interplay in $\mathrm{O}_{3}$ formation and thus may decrease

3 Department of Mushroom Science and Forest Microbiology, Forestry and Forest Products Research Institute (FFPRI), Matsunosato 1, Tsukuba 305-8687, Japan

4 Research Faculty of Agriculture, Hokkaido University, Kita 9 Nishi 9, Sapporo, Hokkaido 060-8589, Japan

5 Department of Plant Ecology, Forestry and Forest Products Research Institute (FFPRI), Matsunosato 1, Tsukuba 305-8687, Japan 
or increase $\mathrm{O}_{3}$ levels (Sicard et al. 2013; Nopmongcol et al. 2017; Li et al. 2019a). Nonetheless, $\mathrm{O}_{3}$ remains at potentially phytotoxic levels throughout the world, especially in wide $\mathrm{O}_{3}$-polluted hotspots in Asia (P. Nagashima et al. 2017; Sicard et al. 2017; Li et al. 2018a, 2019a).

Some of the $\mathrm{O}_{3}$ near plants reacts with volatile organic compounds emitted by plants or is eliminated by leaf trichomes (Li et al. 2016; Oksanen 2018). Other $\mathrm{O}_{3}$ molecules enter the leaf through stomata during gas exchange processes (Paoletti and Grulke 2005). Elevated $\mathrm{O}_{3}$ uptake by stomata can inhibit leaf area growth, decrease carbon uptake and Rubisco and chlorophyll content, alter growth, and suppress productivity of forest plants (Paoletti and Grulke 2005; Wittig et al. 2009; Jolivet et al. 2016; Li et al. 2017a, b; Cailleret et al. 2018). Because of the negative $\mathrm{O}_{3}$ effects on forest plants and associated ecological processes (Karnosky et al. 2005; Ainsworth et al. 2012; Blande et al. 2014; Agathokleous et al. 2016b; Chappelka and Grulke 2016; Braun et al. 2017), we must understand the biology of $\mathrm{O}_{3}$-induced stress and devise innovative methods to mitigate the deleterious effects of $\mathrm{O}_{3}$.

From ancient days, plants have been fertilized using natural sources such as manure. In the modern world, soils have deteriorated and their quality is likely to worsen in the 21st century, requiring greater dependence on synthetic fertilizers as is the case for reforestation seedlings, which commonly receive synthetic fertilizers (Yang et al. 2016). Soil fertility significantly affects plant responses to atmospheric gases (Körner 2009; Bielenberg et al. 2001; Terrer et al. 2016; Koike et al. 2018), soil biota and their interactions with plants, including those between mycorrhiza and plants (Jiang-shan et al. 2005; Terrer et al. 2016; Wang et al. 2018). How soil fertility affects tree-mycorrhizal symbioses under elevated $\mathrm{O}_{3}$, and plant response to $\mathrm{O}_{3}$ overall, has received little attention and remains poorly understood.

Plant-associated soil biota can enhance the tolerance of plants to environmental stress and protect ecosystem stability (Futai et al. 2008; Yang et al. 2018). Mycorrhizae are fungi present in the soil at large scales, and with the rest of the soil microbial community, can drive plant and ecosystem functions (Bolan 1991; van der Heijden et al. 1998). Mycorrhizae enable plants to absorb more nutrients, especially phosphorus $(\mathrm{P})$, and water in exchange for photosynthates (Bolan 1991). Ectomycorrhizae (ECM), which colonize roots without penetrating them, form mutualistic associations with a large proportion of tree species (Futai et al. 2008; Cui and Mu 2016; Wang et al. 2018). Such symbioses can promote plant tolerance to stress (Yin et al. 2016). Preliminary experimentation suggests that fertilization and elevated $\mathrm{O}_{3}$ can alter the diversity of the ECM community and that ECM can enhance the tolerance of associated larch trees to air pollution (Wang et al. 2015, 2018), indicating that ECM are economically important for forestry practice and ecosystem stability. Such research highlights an important area for further studies on soil fertility-ECM- $\mathrm{O}_{3}$ interaction with potential applications in forestry practice.

Japanese larch [Larix kaempferi (Lamb.) Carr] is an ectomycorrhizal coniferous tree species widely distributed in Northeast Asia and planted in wide forested areas of Japan (Fuchen et al. 1998; Ryu et al. 2009). However, this fastgrowing species is also susceptible to diseases (Ryu et al. 2009) and sensitive to $\mathrm{O}_{3}$ (Wang et al. 2015; Agathokleous et al. 2017; Sugai et al. 2018; ) and other stresses (Li et al. 2018b; Wang et al. 2018). Soil fertilization also changes the symbiosis between Japanese larch roots and ECM (Wang et al. 2018) as does elevated $\mathrm{O}_{3}$ for a hybrid larch (L. gmelinii var. japonica $\times$ L. kaempferi), suggesting that Japanese larch may also be similarly affected because it shares half of its genome with this hybrid (Wang et al. 2015). These studies highlight the need for more studies on the Japanese larch association with $\mathrm{ECM}$ under $\mathrm{O}_{3}$ and on how the performance of $\mathrm{O}_{3}$-stressed plants may change as soil fertility changes.

The purpose of this study was to assess the effect of ECM on container-grown Japanese larch seedlings, and the influence of soil nutrients on their interaction under ambient and elevated $\mathrm{O}_{3}$ levels, in a free air $\mathrm{O}_{3}$-concentration enrichment (FACE) system. We hypothesized that ECM can enhance $\mathrm{O}_{3}$ tolerance of plants, which would suppress physiology and inhibit growth of plants due to lower photosynthetic efficiency. However, we hypothesized that the degree of protection will depend on the fertility of the soil because plants may form fewer ectomycorrhizal root tips when nutrients are abundant and directly available.

\section{Materials and methods}

\section{Experimental area}

This experiment was done at the Sapporo Experimental Forest of Hokkaido University, Sapporo, Japan $\left(43^{\circ} 04^{\prime} \mathrm{N}\right.$, $141^{\circ} 20^{\prime} \mathrm{E}, 15 \mathrm{~m}$ a.s.1.) in 2017. Meteorological conditions for this area are presented in (Supplementary Material Table S1).

\section{Plant materials and treatments}

In 2016, seeds of Japanese larch (L. kaempferi) were collected from mother trees naturally grown in Hokkaido, Japan, and stored at low temperature in an incubator. In spring 2017, the seeds were disinfected, then placed on wet paper filter in Petri dishes at room temperature to germinate. Seeds germinated after $10-12$ days (67\% germination). On May 30, among 400 seedlings, 180 healthylooking seedlings were transplanted into 180 pots $(5.5 \mathrm{~cm}$ diameter, $13 \mathrm{~cm}$ height, $0.2-\mathrm{L}$ volume) filled with coco peat 
(topcocopeat, Top, Osaka, Japan) and irrigated until soil runoff. The pots were placed onto plastic flats that had multiple slots to hold the small pots according to recent reforestation practices in Japan because container-grown seedlings have higher survival rates than bare-root seedlings (Masaki et al. 2017). From this point, the soil substrate was kept continuously moist using tap water, until plants were moved to the field. Plants were kept on tables in a glasshouse of Hokkaido University $\left(43^{\circ} 04^{\prime} \mathrm{N}, 141^{\circ} 20^{\prime} \mathrm{E}, 15 \mathrm{~m}\right.$ a.s.l.), with open windows and uncontrolled environment.

The day after transplanting, each plant was treated with $1 \mathrm{~g}$ (low fertilization, hereafter LF) or $2 \mathrm{~g}$ (high fertilization, hereafter HF) slow-release fertilizer (Osmocote Exact Standard 8-9M, 15-9-11 + 2MgO + TE; Hyponex Japan, Osaka, Japan).

On July 8, plants were inoculated with ECM. Briefly, inoculum was obtained from freshly excavated root systems of 5-year-old Japanese larch saplings maintained in the Sapporo Experimental Forest for this purpose. Tap water $(5 \mathrm{~L})$ in two buckets was infested with ECM by agitating ECMinfected roots for $10 \mathrm{~min}$. The water of the one bucket was subsequently sterilized by boiling for $40 \mathrm{~min}$. After sterilization, $5 \mathrm{~L}$ of cold tap water was added to each bucket. The glasshouse was separated into two similar sides by closing a glass door in the middle. Half of the plants from each fertilization treatment were moved to the other half of the glasshouse. Plants in the one half of the glasshouse received $100 \mathrm{~mL}$ of sterilized water each (hereafter, non-ECM). Plants in the other half received $100 \mathrm{~mL}$ of non-sterilized water each (ECM).

On July 21, damping off symptoms were observed on some seedlings of both ECM treatments. Seedlings with such symptoms were moved to a field with no nearby vegetation, and, all the remaining non-ECM plants were treated (a dilution of 1000) with a fungicide (Sankyo Thiuram 80, HOKUSAN, Kitahiroshima, Hokkaido, Japan). ECM plants were treated with only water. All plants were treated at night when stomata were closed. This treatment was repeated 9 days later. With the same methods, on July 25, non-ECM plants were sprayed (1:000) again with fungicide (Tachigaren, MITSUI CHEMICALS AGRO, Tokyo, Japan). This treatment was repeated on August 1.

The experimental design, for the duration plants remained in the glasshouse, was fully randomized, and the position of the plants was rotated on a weekly basis.

On August 2, all plants were moved outside to moderate shade to acclimate to field conditions, then transferred to the FACE system on August 11. Plants were not irrigated manually for the duration of the $\mathrm{O}_{3}$ treatments.

The $\mathrm{O}_{3}$ treatments in the FACE system of Hokkaido University, Sapporo, Japan (Agathokleous et al. 2017) included ambient $\mathrm{O}_{3}(\mathrm{AOZ})$ and elevated $\mathrm{O}_{3}(\mathrm{EOZ})$. For $\mathrm{EOZ}, \mathrm{O}_{3}$-enrichment was performed on a daily basis during the daytime, from August 18 to October 28. To increase the experimental robustness by accounting for environmental variability, two subplots were created in each FACE plot by placing 3-4 pots/plants per fertilizer and ECM treatments in a multiwall plastic flat (completely randomized); one flat was placed on the south side of each plot, and the other on the north side of each plot for a total of 18 plants on average per fertilizer, ECM, and $\mathrm{O}_{3}$ treatments.

The plants in each $\mathrm{O}_{3}$ treatment were rotated among the experimental units approximately every 10 days. Ambient $\mathrm{O}_{3}$ levels were recorded continuously (1-min intervals) using an ultraviolet absorption $\mathrm{O}_{3}$ analyzer (TUV-1100; Tokyo Industries, Tokyo, Japan). The average daily 10-h (08:00-18:00 h Japan Standard Time, JST) ambient $\mathrm{O}_{3}$ level over the treatment period was $39.1( \pm 6.0 \mathrm{SD}) \mathrm{nmol} \mathrm{mol}^{-1}$. In the three EOZ plots, the average daily 10-h (07:00-17:00 h JST) $\mathrm{O}_{3}$ level over the treatment period was $65.2( \pm 4.3 \mathrm{SD})$ nmol mol${ }^{-1}$, i.e. $~ 1.7$ times the ambient $\mathrm{O}_{3}$ level.

\section{Data collection}

\section{Gas exchange}

Gas exchange was measured in situ using a LiCor gas exchange systems (LI-6400, Li-Cor, Lincoln, NE, USA) from 8 to 10 October. Stomatal conductance $\left(\mathrm{Gs}_{390}\right)$, photosynthetic rate $\left(A_{390}\right)$ and transpiration rate $\left(E_{390}\right)$ were determined at $390 \mu \mathrm{mol} \mathrm{mol}^{-1} \mathrm{CO}_{2}, 60 \pm 5 \%$ relative air humidity, and $1500 \mu \mathrm{mol} \mathrm{m}^{-2} \mathrm{~s}^{-1}$ light. Leaf temperature was maintained at $25^{\circ} \mathrm{C}$. After recording $\mathrm{Gs}_{390}$ and $A_{390}$, the light was set to $100 \mu \mathrm{mol} \mathrm{m} \mathrm{m}^{-2} \mathrm{~s}^{-1}$, and $\mathrm{Gs}_{390}$ and $A_{390}$ were recorded again 15 min later. The response of $\mathrm{Gs}_{390}$ and $A_{390}$ to light was calculated as the percentage of change in the values of $\mathrm{Gs}_{390}$ and $A_{390}$ recorded at $100 \mu \mathrm{mol} \mathrm{m}{ }^{-2} \mathrm{~s}^{-1}\left(\mathrm{Gs}_{100}\right.$ and $\left.A_{100}\right)$ relative to those recorded at $1500 \mu \mathrm{mol} \mathrm{m}^{-2} \mathrm{~s}^{-1}\left(\mathrm{Gs}_{1500}\right.$ and $A_{1500}$ ). Gas exchange was measured in randomly selected sunlit mature needles, and the projected area of the measured needles was estimated (software LAI-32 v. 0.377e, Dr. Yamamoto K, Graduate School of Bioagricultural Sciences, Nagoya University, Japan) after scanning the needles (Canon LIDE 40, Tokyo, Japan). Gas exchange was measured in the morning and completed by 11:00 $\mathrm{h}$ JST.

\section{Growth}

Growth traits were measured on each plant on November 2 . The stem height was measured as the distance from the soil surface to the top of the stem. The plant height was measured as the distance from the soil surface to the top of the crown. The height at which the crown starts (from the soil surface) was also measured, and the depth of the crown was estimated by subtracting the height at which the crown starts from the plant height. The crown span was measured by 
taking two crosswise measurements (the two widest points of the crown) using a measuring tape with 1-mm scaling. The stem basal diameter was also measured by taking two cross measurements per plant using a digital vernier caliper with 0.001 accuracy.

\section{Productivity}

The seedlings were harvested on December 7 and separated into leaves, shoots and stem. Roots were washed gently to remove all soil particles, and their length was measured. Samples were air-dried at $75^{\circ} \mathrm{C}$ to constant mass. The buds on each plant were counted. Stems (with branches) and foliage were weighed for each plan. Shoot dry matter was calculated by summing the foliage dry matter and stem dry matter per plant.

\section{Root ECM traits}

At the end of the experiment, roots were analyzed only for seedlings grown in the presence of LF to confirm the effectiveness of the ECM treatment. Therefore, three plants were analyzed for each $\mathrm{O}_{3}$ treatment for the ECM-treated plants and four for each $\mathrm{O}_{3}$ treatment for the non-ECM-treated plants. The plants of each treatment had similar heights, and $\operatorname{ECM}(F=0.20, P=0.664), \mathrm{O}_{3} \times \mathrm{ECM}(F<0.01, P=0.981)$ and $\mathrm{ECM} \times \mathrm{O}_{3}(F=1.92, P=0.197)$ had no statistically significant effect. The root traits analyzed were (1) total number of root tips with fully formed mycorrhizae (with a perfect mantle, permitting categorization into morphological types), (2) total number of nonmycorrhizal roots, (3) total number of root tips with mycorrhiza forming (i.e., incomplete mycorrhizae with no mantle), and (4) total number of roots with no root tip or aerial cut of root tip. The analyses were conducted using an electronic stereoscope connected to a computer. The total number of roots was calculated as the sum of the four measured root traits. The total number of root tips with fully formed mycorrhizae was 0 for all the measurements.

DNA of the ITS1-ITS2 regions (5.8S rDNA) was analyzed. The basic local alignment search tool (BLAST) for the GenBank database of NCBI was used to identify the symbiotic microorganisms as described previously (Wang et al. 2015).

\section{Survival from damping off}

By the end of the experiment (November), seedlings with damping off in August were dead. These dead plants were counted, and the survival rate of plants in each fertilization treatment was calculated as $\left(N_{\text {alive }} / N_{\text {total }}\right) \times 100$ where $N_{\text {alive }}$ is the number of alive/healthy plants and $N_{\text {total }}$ is the initial total number of healthy plants before damping off.

\section{Leaf and root chemical composition}

After the harvest, the dried foliage from one or two plants was pooled to obtain a composite sample for analysis, then ground to a fine powder. The same was done for the roots. These samples were digested in $\mathrm{HNO}_{3}$ using $100 \mathrm{~mL}$ PP tubes (DigiTUBES, SCP Science, New York, USA) and a thermal unit (DigiPREP, SCP Science, New York, USA) at $105^{\circ} \mathrm{C}$. The digested residue was diluted with $2 \%(\mathrm{v} / \mathrm{v})$ $\mathrm{HNO}_{3}$ and filtered through a $0.45 \mu \mathrm{m}$ Teflon membrane filter (DigiFILTER, SCP Science). The Al, B, Ca, Fe, K, $\mathrm{Mg}, \mathrm{Mn}, \mathrm{Na}, \mathrm{P}$, and $\mathrm{Zn}$ concentrations in the samples were determined by inductively coupled plasma mass spectrometry (ICP-MS, Agilent 7700a, Agilent Technologies, Santa Clara, CA, USA).

\section{Statistical analysis of data}

When more than one measurement was taken per plant, the data were averaged per plant. Because all the plants were rotated among the experimental units of each $\mathrm{O}_{3}$ treatment, for each response variable, the plant-level data ( $n=8-20$ per experimental condition) were allocated to three groups using sampling without replacement. The data for each group $(n=2-7)$ were then averaged to give one robust estimate per virtual experimental unit (i.e., statistical unit), hence, resulting in 3 values per experimental condition $(n=3)$ for further statistical testing. This process was followed for all the response variables except seedling survival.

A level of statistical significance of $\alpha=0.05$ was chosen a priori. Data were tested for normality with a $\chi^{2}$ test. Data for survival rate, stem height, crown depth and crown width in November, growth (except stem diameter), production and nutrient data, $\mathrm{Gs}_{100}$ and $A_{100}$, and root tip traits deviated significantly $(P<0.05)$ from normal distribution and thus were transformed using a Box-Cox transformation (Box and Cox 1964), as described previously (Agathokleous et al. 2016a),

Survival rate data were matched to a sigma-restricted type III generalized linear model (GLM) with Fertilizer as fixed factor. Data for gas exchange, light response, growth and production were subjected to a sigma-restricted type III GLM with fertilizer, ECM and $\mathrm{O}_{3}$ as fixed factors and plot as the random factor. Data for root tip traits were subjected to a GLM with a sigma-restricted type VI parameterization; ECM and $\mathrm{O}_{3}$ were fixed factors. When GLMs revealed a significant interaction, Bonferroni test followed for multiple comparisons among the experimental groups. The results are reported as mean \pm SE. EXCEL 2010 (Microsoft, Redmond, CA, USA) and STATISTICA v.10 (StatSoft, Tulsa, OK, USA) software was used for all data processing and statistics. 
Fig. 1 Mean values $\pm \operatorname{SE}(n=3)$ for gas exchange variables in Japanese larch seedlings grown in two soil fertilization regimes, treated with ectomycorrhizae and no fungicide (ECM) or sterilized water and fungicide (nonECM) and exposed to ambient (AOZ) or elevated (EOZ) ozone $\left(\mathrm{O}_{3}\right) \cdot \mathrm{A}_{390}$, net photosynthetic rate; $\mathrm{Gs}_{390}$, stomatal conductance; and $\mathrm{E}_{390}$, transpiration rate. An asterisk indicates significant single effect and "ns" indicates nonsignificant single effect, within a response variable, according to a generalized linear model at $\alpha=0.05$.

The only significant interaction was Fertilizer $\times \mathrm{ECM}$ for $E_{390}$; in particular, between plants treated with ECM in LF and non-ECM plants in LF (Bonferroni post hoc test)
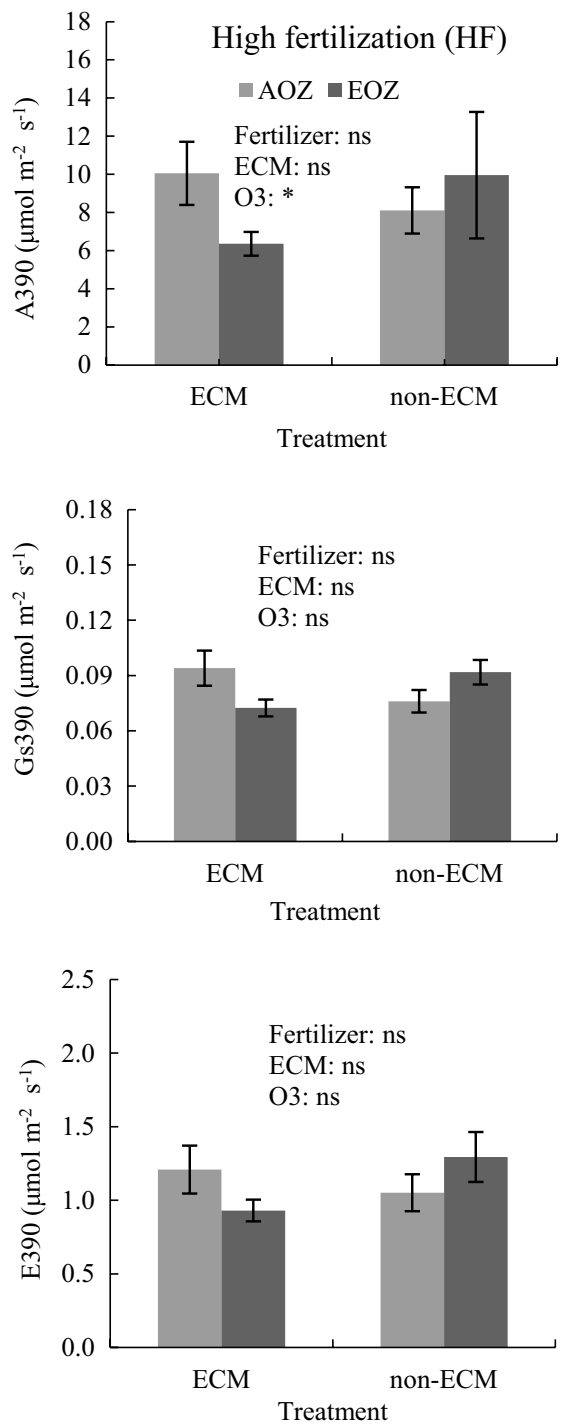
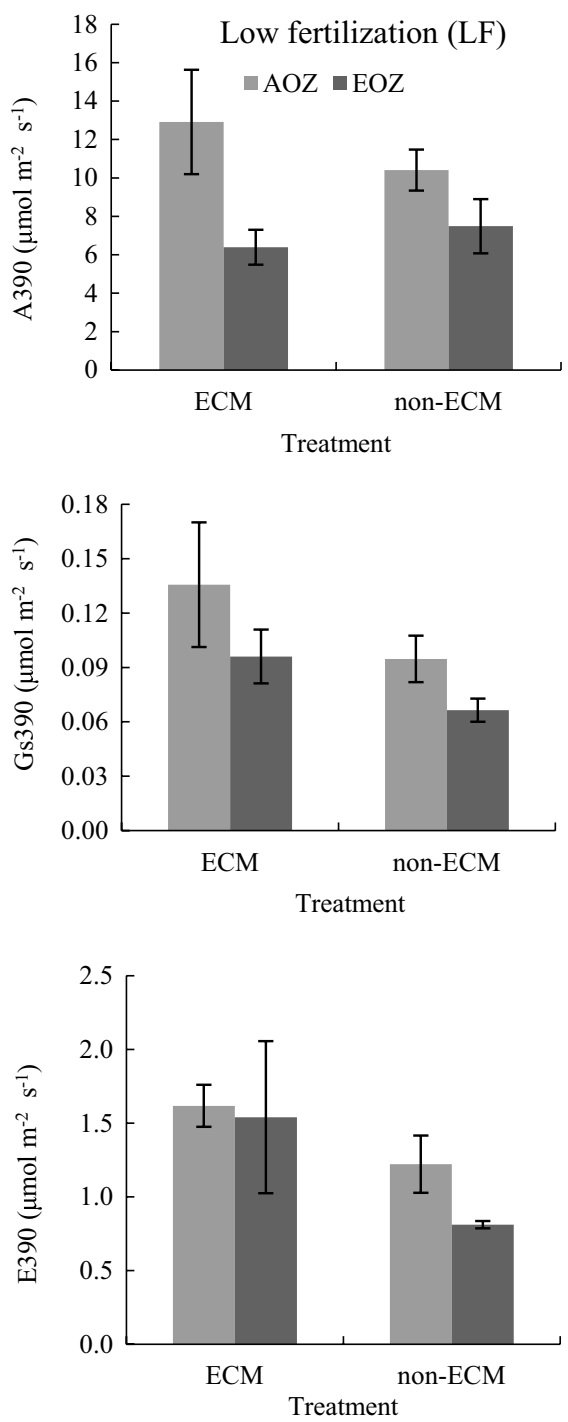

\section{Results}

\section{Gas exchange}

$A_{390}$ was $29 \%$ lower in EOZ than in $\mathrm{AOZ}$ and was not significantly affected by other treatments (Fig. 1, Table 1). Although $\mathrm{Gs}_{390}$ was $18 \%$ lower in $\mathrm{EOZ}$ than in $\mathrm{AOZ}$, the difference was statistically nonsignificant. $\mathrm{Gs}_{390}$ was not significantly affected by other treatments. However, the only factors significantly affecting $E_{390}$ were the interactions Fertilizer $\times \mathrm{ECM}$ and Fertilizer $\times \mathrm{ECM} \times \mathrm{O}_{3}$. For the interaction Fertilizer $\times$ ECM, the only significant difference among groups was a $60 \%$ higher $E_{390}$ in plants treated with ECM in LF than in non-ECM plants in LF. Regarding the interaction Fertilizer $\times \mathrm{ECM} \times \mathrm{O}_{3}$, there was only one significant difference among groups, which had no biological relevance $(\mathrm{ECM} \times \mathrm{LF} \times \mathrm{AOZ}$ vs. non-ECM $\times$ LF $\times$ EOZ).
The response of $\mathrm{Gs}_{390}$ and $A_{390}$ to light ( $\% \mathrm{Gs}_{390}$ and $\% \mathrm{~A}_{390}$ ) was not significantly affected by any treatment (Fig. 2, Table 1).

\section{Plant growth}

Stem height was significantly affected by fertilizer only, with HF plants having 1.29 times higher stem height than LF plants (Fig. 3, Table 1). Roots were $20 \%$ longer in AOZ than in EOZ (Fig. 3, Table 1). Crown depth was affected only by fertilizer, with HF plants having 1.18 times greater crown depth than LF plants (Fig. 4, Table 1). Crown span was increased by $\mathrm{HF}(+17 \%)$, compared to $\mathrm{LF}$, and decreased by EOZ ( $-8 \%)$, compared to AOZ; no other factors were significant. Stem diameter was higher in $\mathrm{HF}(+11 \%)$ than in LF, lower in EOZ $(-21 \%)$ than in AOZ, and lower in ECM plants $(-10 \%)$ than in non-ECM plants; interactions were nonsignificant (Fig. 3, Table 1). 
Table 1 Statistical results of gas exchange, light response and growth traits

\begin{tabular}{|c|c|c|c|c|c|c|c|}
\hline Gas exchange & Fertilizer & ECM & $\mathrm{O}_{3}$ & Fertilizer $\times \mathrm{O}_{3}$ & Fertilizer $\times \mathrm{ECM}$ & $\mathrm{ECM} \times \mathrm{O}_{3}$ & $\begin{array}{l}\text { Ferti- } \\
\text { lizer } \times \mathrm{ECM} \times \mathrm{O}_{3}\end{array}$ \\
\hline $\mathrm{A}_{390}$ & $\begin{aligned} F & =0.27 \\
P & =0.614\end{aligned}$ & $\begin{aligned} F= & 0.08, \\
P & =0.788\end{aligned}$ & $F=7.7, P<0.05$ & $\begin{array}{l}F=1.57 \\
P=0.228\end{array}$ & $\begin{array}{l}F=0.04 \\
P=0.848\end{array}$ & $\begin{aligned} F & =2.55, \\
P & =0.130\end{aligned}$ & $\begin{array}{l}F=0.22 \\
P=0.644\end{array}$ \\
\hline $\mathrm{Gs}_{390}$ & $\begin{array}{l}F=0.63 \\
P=0.441\end{array}$ & $\begin{aligned} F= & 2.50, \\
P & =0.134\end{aligned}$ & $\begin{array}{l}F=3.45, \\
P=0.082\end{array}$ & $\begin{aligned} F= & 2.29, \\
P & =0.150\end{aligned}$ & $\begin{aligned} F & =3.29 \\
P & =0.088\end{aligned}$ & $\begin{array}{l}F=0.75 \\
P=0.401\end{array}$ & $\begin{array}{l}F=3.02, \\
P=0.102\end{array}$ \\
\hline$E_{390}$ & $\begin{aligned} F & =0.39 \\
P & =0.542\end{aligned}$ & $\begin{aligned} F= & 2.58, \\
P & =0.128\end{aligned}$ & $\begin{aligned} F & =3.80 \\
P & =0.069\end{aligned}$ & $\begin{aligned} F & =2.60, \\
P & =0.126\end{aligned}$ & $\begin{aligned} F & =7.68 \\
P & <0.05^{\mathrm{a}}\end{aligned}$ & $\begin{aligned} F= & 0.33 \\
P & =0.574\end{aligned}$ & $\begin{aligned} F & =4.37 \\
P & =0.053\end{aligned}$ \\
\hline \multicolumn{8}{|l|}{ Light response } \\
\hline $\mathrm{Gs}_{100}$ & $\begin{array}{l}F=0.19 \\
P=0.669\end{array}$ & $\begin{aligned} F & =0.01 \\
P & =0.934\end{aligned}$ & $\begin{array}{l}F=1.13 \\
P=0.304\end{array}$ & $\begin{aligned} F & =0.69 \\
P & =0.418\end{aligned}$ & $\begin{aligned} F & =0.57 \\
P & =0.462\end{aligned}$ & $\begin{array}{c}F=0.16 \\
P=0.695\end{array}$ & $\begin{array}{l}F=0.15, \\
P=0.709\end{array}$ \\
\hline $\mathrm{A}_{100}$ & $\begin{aligned} F & =1.54 \\
P & =0.232\end{aligned}$ & $\begin{aligned} F & =0.08 \\
P & =0.786\end{aligned}$ & $\begin{aligned} F & =2.29 \\
P & =0.150\end{aligned}$ & $\begin{aligned} F= & 0.73 \\
P & =0.405\end{aligned}$ & $\begin{aligned} F & =0.29 \\
P & =0.599\end{aligned}$ & $\begin{array}{l}F<0.01 \\
P=0.974\end{array}$ & $\begin{array}{l}F=0.01, \\
P=0.930\end{array}$ \\
\hline \multicolumn{8}{|l|}{ Growth } \\
\hline Stem height & $\begin{array}{r}F=13.65, \\
P<0.01\end{array}$ & $\begin{aligned} F & =2.26 \\
P & =0.152\end{aligned}$ & $\begin{array}{l}F<0.01 \\
P=0.994\end{array}$ & $\begin{array}{l}F=0.04 \\
P=0.847\end{array}$ & $\begin{aligned} & F<0.01 \\
& P=0.992\end{aligned}$ & $\begin{array}{l}F=0.04, \\
P=0.850\end{array}$ & $\begin{array}{l}F=1.90 \\
P=0.188\end{array}$ \\
\hline Stem diameter & $\begin{array}{r}F=7.04 \\
P<0.05\end{array}$ & $\begin{array}{r}F=6.86 \\
P<0.05\end{array}$ & $\begin{aligned} F= & 35.07 \\
P & <0.001\end{aligned}$ & $\begin{array}{l}F=0.01, \\
P=0.908\end{array}$ & $\begin{array}{l}F=3.61, \\
P=0.076\end{array}$ & $\begin{aligned} F & =3.56, \\
P & =0.078\end{aligned}$ & $\begin{array}{l}F=1.33 \\
P=0.266\end{array}$ \\
\hline Crown depth & $\begin{array}{r}F=7.79 \\
P<0.05\end{array}$ & $\begin{array}{l}F=1.04, \\
P=0.324\end{array}$ & $\begin{aligned} F & =1.37 \\
P & =0.259\end{aligned}$ & $\begin{aligned} F= & 0.04 \\
P & =0.852\end{aligned}$ & $\begin{array}{l}F=1.21, \\
P=0.288\end{array}$ & $\begin{array}{l}F=0.10, \\
P=0.752\end{array}$ & $\begin{array}{l}F=0.76 \\
P=0.396\end{array}$ \\
\hline Crown span & $\begin{aligned} & F=16.54 \\
& P<0.001\end{aligned}$ & $\begin{aligned} F & =4.35 \\
P & =0.053\end{aligned}$ & $\begin{aligned} F=5.02 \\
P<0.05\end{aligned}$ & $\begin{aligned} F & =0.40 \\
P & =0.536\end{aligned}$ & $\begin{aligned} F= & 0.88 \\
P & =0.362\end{aligned}$ & $\begin{array}{l}F=0.10 \\
P=0.762\end{array}$ & $\begin{array}{l}F=3.01, \\
P=0.102\end{array}$ \\
\hline Root length & $\begin{array}{l}F=0.03 \\
P=0.877\end{array}$ & $\begin{array}{l}F=0.01, \\
P=0.911\end{array}$ & $\begin{aligned} & F=7.45 \\
& P<0.05\end{aligned}$ & $\begin{aligned} F= & 0.77 \\
P & =0.394\end{aligned}$ & $\begin{array}{l}F=0.04, \\
P=0.843\end{array}$ & $\begin{array}{l}F=0.20, \\
P=0.658\end{array}$ & $\begin{aligned} F= & 0.34 \\
P & =0.567\end{aligned}$ \\
\hline
\end{tabular}

The data were tested using a generalized linear model $(\alpha=0.05)$. Values in bold indicate statistical significance. Data are presented in Figs. 1, 2, 3 and 4

${ }^{a}$ The only significant difference among groups was between plants treated with ECM in LF and non-ECM plants in LF

Fig. 2 Mean values $\pm \operatorname{SE}(n=3)$ of light response variables in Japanese larch seedlings grown in two soil fertilization regimes, treated with ectomycorrhizae and no fungicide (ECM) or sterilized water and fungicide (nonECM) and exposed to ambient (AOZ) or elevated (EOZ) ozone $\left(\mathrm{O}_{3}\right) . \mathrm{A}_{390}$, net photosynthetic rate; $\mathrm{Gs}_{390}$, stomatal conductance. Values are percentage of change in $\mathrm{Gs}_{390}$ and $A_{390}$ recorded at $100 \mu \mathrm{mol} \mathrm{m}^{-2} \mathrm{~s}^{-1}$ $\left(\mathrm{Gs}_{100}\right.$ and $\left.A_{100}\right)$ from those recorded at $1500 \mu \mathrm{mol} \mathrm{m}^{-2} \mathrm{~s}^{-1}$ $\left(\mathrm{Gs}_{1500}\right.$ and $\left.\mathrm{A}_{1500}\right)$. None of the single or interactive effects were significant according to a generalized linear model at $\alpha=0.05$
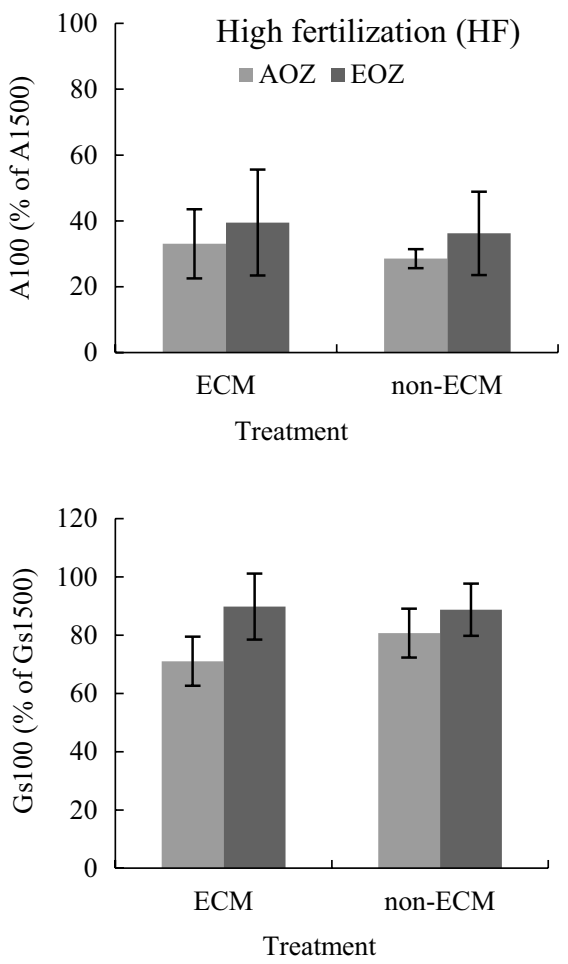

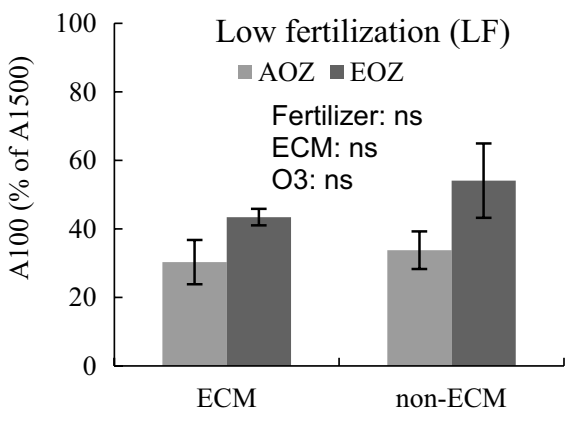

Treatment

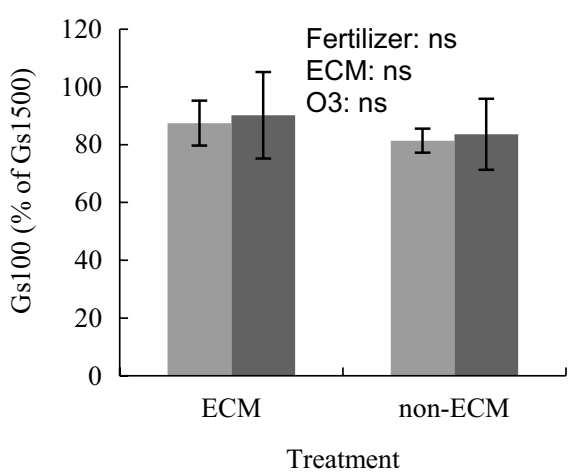


Fig. 3 Mean values \pm SE $(n=3)$ of plant growth traits of Japanese larch seedlings grown in two soil fertilization regimes, treated with ectomycorrhizae and no fungicide (ECM) or sterilized water and fungicide (non-ECM) and exposed to ambient (AOZ) or elevated (EOZ) ozone $\left(\mathrm{O}_{3}\right)$. An asterisk indicates significant single effect and "ns" indicates nonsignificant single effect, within a response variable, according to a generalized linear model at $\alpha=0.05$. No interactions were significant
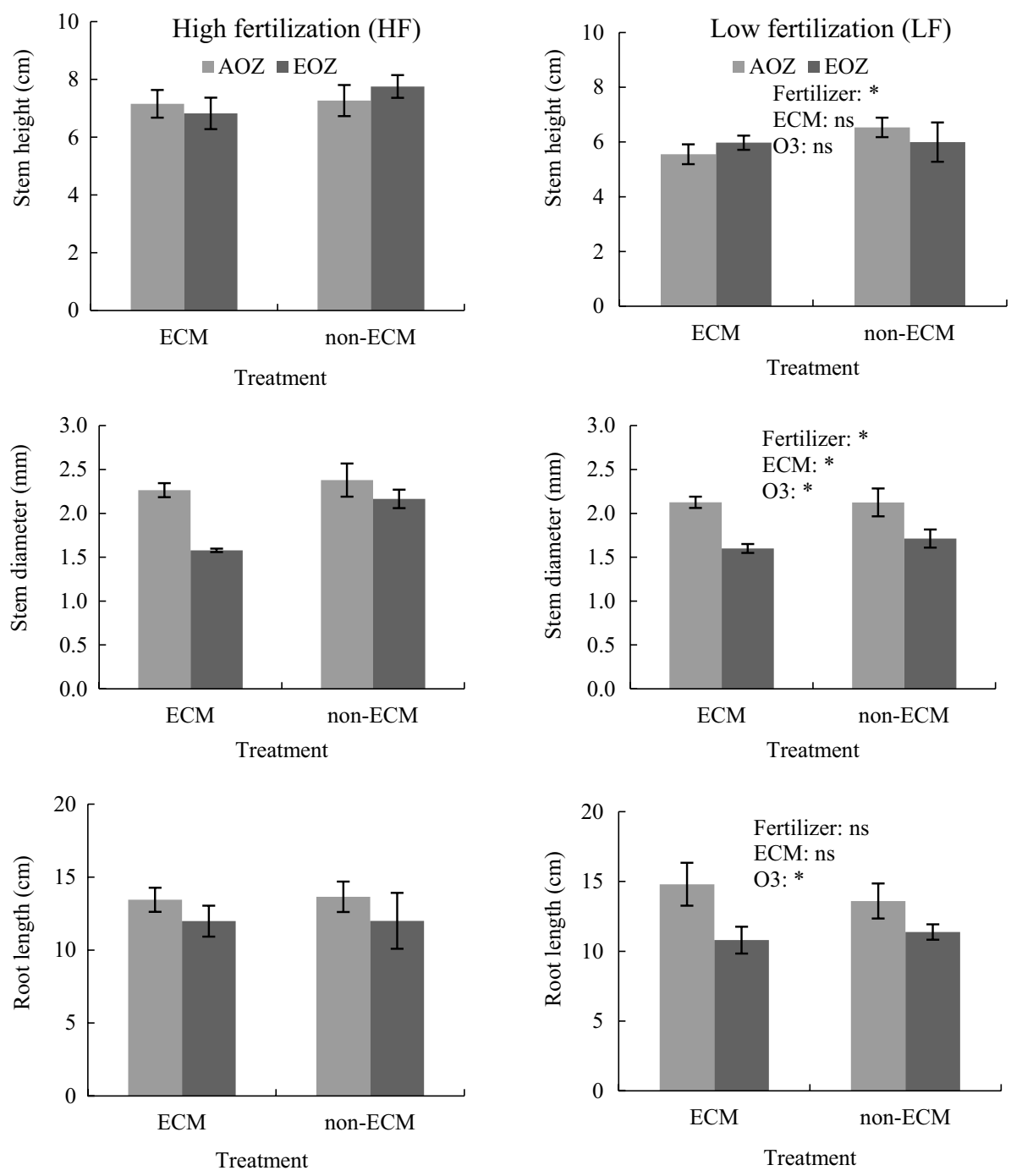

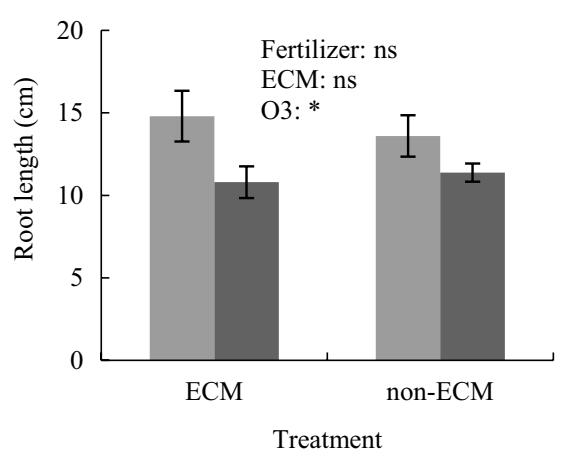

\section{Plant productivity}

Plants in HF (mean 14.9) had 55\% more buds than plants in LF (mean 9.6) (Table 2, Supplementary Materials Fig. S1). Roots, foliage, stems and total plant dry mass were not significantly affected by any treatment (Supplementary Material Fig. S2), as was also the case for the ratio of root dry mass to foliage dry mass $(\mathrm{R} / \mathrm{F})$ and root dry mass to root dry mass (R/S) (Supplementary Material Fig. S3), number of buds per root dry matter, and number of buds per total plant dry mass (Table 2). While the mean dry mass was much higher in HF than in LF, there were large variances (Supplementary Material Fig. S2), and the results were nonsignificant (Table 2).

\section{Root-ECM traits}

Analysis of root as to ECM-forming capacity (Fig. 5) revealed that the values of non-mycorrhizal roots, forming mycorrhizal roots, no root tip roots, and total number of root tips of ECM-treated plants were on average 197, 183, 210 , and $185 \%$ of the values of non-ECM-treated plants, respectively (Table 3 ). $\mathrm{O}_{3}$, as a single factor, was nonsignificant for all traits. The $\mathrm{ECM} \times \mathrm{O}_{3}$ interaction was significant for nonmycorrhizal roots and no-root-tip roots only. Nonmycorrhizal roots did not differ significantly between non-ECM-treated and ECM-treated plants in AOZ; however, in EOZ, the mean value was 7.8 times lower in nonECM-treated plants than in ECM-treated plants (Table 3). Similarly, no root tip roots differed significantly between non-ECM-treated and ECM-treated plants in AOZ; however, in EOZ, the mean value was 4.4 times lower in nonECM-treated plants than in ECM-treated plants.

The BLAST analysis revealed that ECM-treated seedlings were infected only with Fusarium sp. and untreated seedlings were infected with Suillus grevillei and Dothideomycetes sp. 
Fig. 4 Mean values $\pm \operatorname{SE}(n=3)$ for crown growth traits of Japanese larch seedlings grown in two soil fertilization regimes, treated with ectomycorrhizae and no fungicide (ECM) or sterilized water and fungicide (non-ECM) and exposed to ambient (AOZ) or elevated (EOZ) ozone $\left(\mathrm{O}_{3}\right)$. An asterisk indicates significant single effect and "ns" indicates nonsignificant single effect, within a response variable, according to a generalized linear model at $\alpha=0.05$. No interactions were significant
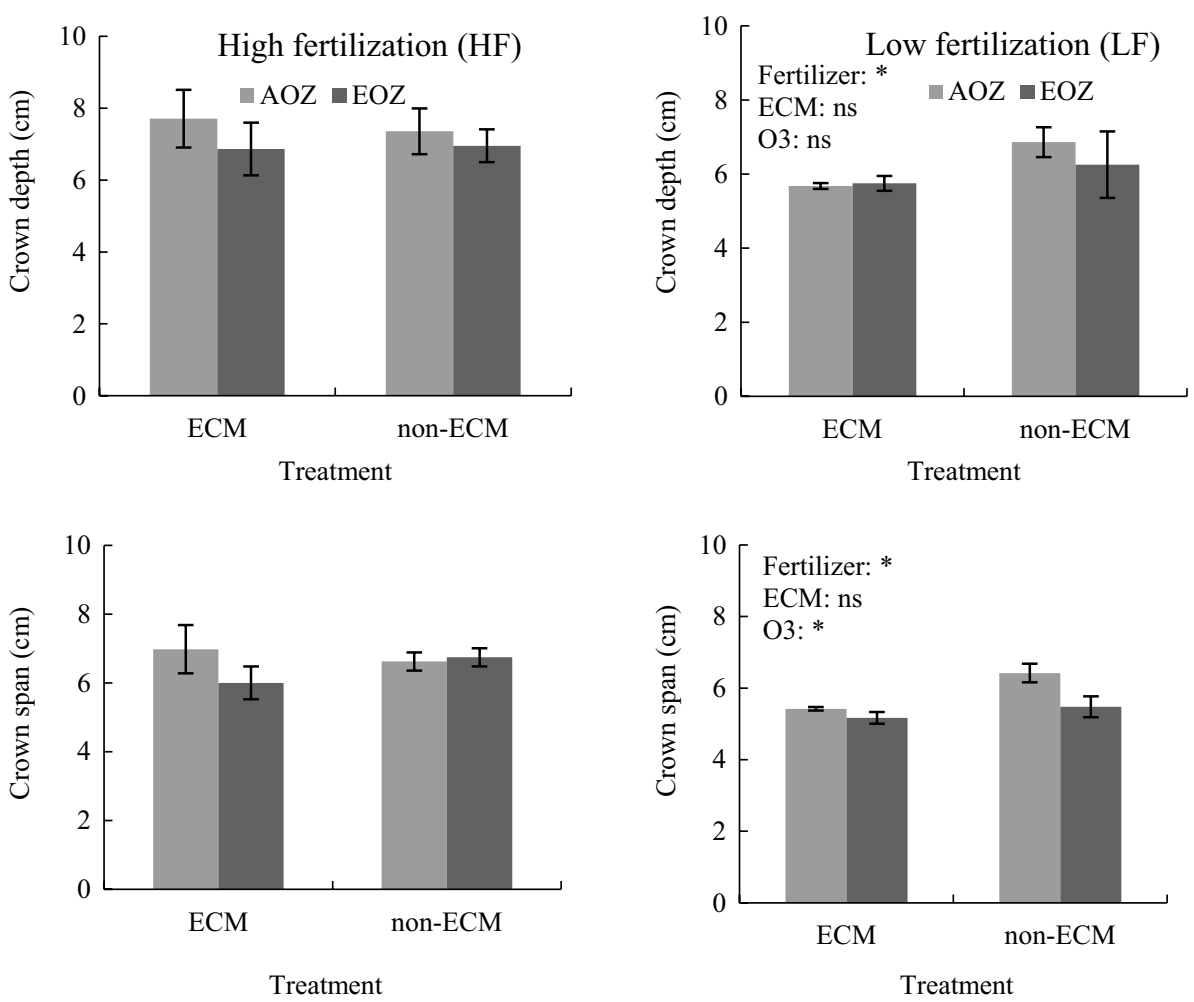

Table 2 Statistical results of production traits

\begin{tabular}{|c|c|c|c|c|c|c|c|}
\hline Trait & Fertilizer & ECM & $\mathrm{O}_{3}$ & Fertilizer $\times \mathrm{O}_{3}$ & $\begin{array}{l}\text { Ferti- } \\
\text { lizer } \times \mathrm{ECM}\end{array}$ & $\mathrm{ECM} \times \mathrm{O}_{3}$ & $\begin{array}{l}\text { Ferti- } \\
\text { lizer } \times \mathrm{ECM} \times \mathrm{O}_{3}\end{array}$ \\
\hline No. of buds & $\begin{array}{r}F=4.72 \\
P<0.05\end{array}$ & $\begin{array}{l}F=0.42, \\
P=0.529\end{array}$ & $\begin{array}{l}F=0.01, \\
P=0.923\end{array}$ & $\begin{array}{l}F=0.20 \\
P=0.662\end{array}$ & $\begin{array}{l}F=0.13, \\
P=0.724\end{array}$ & $\begin{array}{l}F=1.03 \\
P=0.325\end{array}$ & $\begin{array}{l}F=1.18 \\
P=0.294\end{array}$ \\
\hline Root dry mass & $\begin{array}{l}F=2.04, \\
P=0.172\end{array}$ & $\begin{array}{l}F=0.14 \\
P=0.717\end{array}$ & $\begin{aligned} F=1.82 \\
P=0.196\end{aligned}$ & $\begin{aligned} F=0.03 \\
P=0.862\end{aligned}$ & $\begin{array}{l}F=0.17 \\
P=0.687\end{array}$ & $\begin{array}{l}F=0.47 \\
P=0.504\end{array}$ & $\begin{array}{l}F=0.60 \\
P=0.449\end{array}$ \\
\hline $\begin{array}{l}\text { Foliage dry } \\
\text { mass }\end{array}$ & $\begin{aligned} F & =4.28 \\
P & =0.055\end{aligned}$ & $\begin{array}{l}F=0.01 \\
P=0.919\end{array}$ & $\begin{aligned} & F=1.05 \\
& P=0.322\end{aligned}$ & $\begin{array}{l}F=0.05 \\
P=0.833\end{array}$ & $\begin{array}{l}F=0.02 \\
P=0.885\end{array}$ & $\begin{array}{l}F=0.19 \\
P=0.666\end{array}$ & $\begin{aligned} F= & 0.64 \\
P & =0.437\end{aligned}$ \\
\hline Stem dry mass & $\begin{aligned} F & =2.64, \\
P & =0.124\end{aligned}$ & $\begin{array}{l}F=0.60, \\
P=0.451\end{array}$ & $\begin{array}{l}F=0.28 \\
P=0.607\end{array}$ & $\begin{array}{l}F=0.45 \\
P=0.513\end{array}$ & $\begin{aligned} F & <0.01 \\
P & =0.965\end{aligned}$ & $\begin{array}{l}F=0.11 \\
P=0.741\end{array}$ & $\begin{array}{l}F=0.06 \\
P=0.817\end{array}$ \\
\hline Plant dry mass & $\begin{array}{l}F=2.79, \\
P=0.114\end{array}$ & $\begin{array}{l}F=0.17 \\
P=0.686\end{array}$ & $\begin{array}{l}F=1.10 \\
P=0.309\end{array}$ & $\begin{array}{l}F=0.03 \\
P=0.864\end{array}$ & $\begin{array}{l}F=0.07 \\
P=0.799\end{array}$ & $\begin{array}{l}F=0.27 \\
P=0.612\end{array}$ & $\begin{array}{l}F=0.46 \\
P=0.510\end{array}$ \\
\hline $\mathrm{R} / \mathrm{F}$ ratio & $\begin{aligned} F & =0.76 \\
P & =0.395\end{aligned}$ & $\begin{aligned} F= & 0.28 \\
P & =0.603\end{aligned}$ & $\begin{array}{l}F=1.86 \\
P=0.191\end{array}$ & $\begin{array}{l}F=1.13 \\
P=0.304\end{array}$ & $\begin{aligned} F & =0.59 \\
P & =0.453\end{aligned}$ & $\begin{array}{l}F=0.63 \\
P=0.440\end{array}$ & $\begin{array}{l}F=0.09 \\
P=0.763\end{array}$ \\
\hline $\mathrm{R} / \mathrm{S}$ ratio & $\begin{aligned} F= & 0.47, \\
P & =0.503\end{aligned}$ & $\begin{aligned} F=0.04 \\
P=0.851\end{aligned}$ & $\begin{aligned} F & =2.95 \\
P & =0.105\end{aligned}$ & $\begin{array}{l}F=2.81, \\
P=0.113\end{array}$ & $\begin{array}{l}F=1.19, \\
P=0.291\end{array}$ & $\begin{array}{l}F=1.09 \\
P=0.312\end{array}$ & $\begin{array}{l}F=0.73 \\
P=0.406\end{array}$ \\
\hline $\begin{array}{l}\text { Buds/root dry } \\
\text { mass }\end{array}$ & $\begin{aligned} F & =0.75, \\
P & =0.399\end{aligned}$ & $\begin{aligned} F<0.01 \\
\quad P=0.968\end{aligned}$ & $\begin{aligned} F= & 2.00 \\
P & =0.176\end{aligned}$ & $\begin{array}{l}F=0.13 \\
P=0.720\end{array}$ & $\begin{aligned} F= & 0.81 \\
P & =0.383\end{aligned}$ & $\begin{array}{l}F=0.08 \\
P=0.776\end{array}$ & $\begin{aligned} & F<0.01 \\
& \quad P=0.949\end{aligned}$ \\
\hline $\begin{array}{l}\text { Buds/total dry } \\
\text { mass }\end{array}$ & $\begin{array}{l}F=0.01, \\
P=0.924\end{array}$ & $\begin{array}{l}F=0.01, \\
P=0.919\end{array}$ & $\begin{array}{l}F=2.98, \\
P=0.104\end{array}$ & $\begin{array}{l}F=0.67, \\
P=0.425\end{array}$ & $\begin{array}{l}F=1.17 \\
P=0.296\end{array}$ & $\begin{array}{l}F=0.23 \\
P=0.637\end{array}$ & $\begin{array}{l}F=0.01, \\
P=0.932\end{array}$ \\
\hline
\end{tabular}

The data were tested using a generalized linear model at $\alpha=0.05$. Values in bold indicate statistical significance. R/F, ratio of root dry mass to foliage dry mass; R/S, ratio of root dry mass to root dry mass; buds/root mass, number of buds per root dry mass; buds/total dry mass, number of buds per total plant dry mass. Data are presented in Supplementary Material S1-S3 


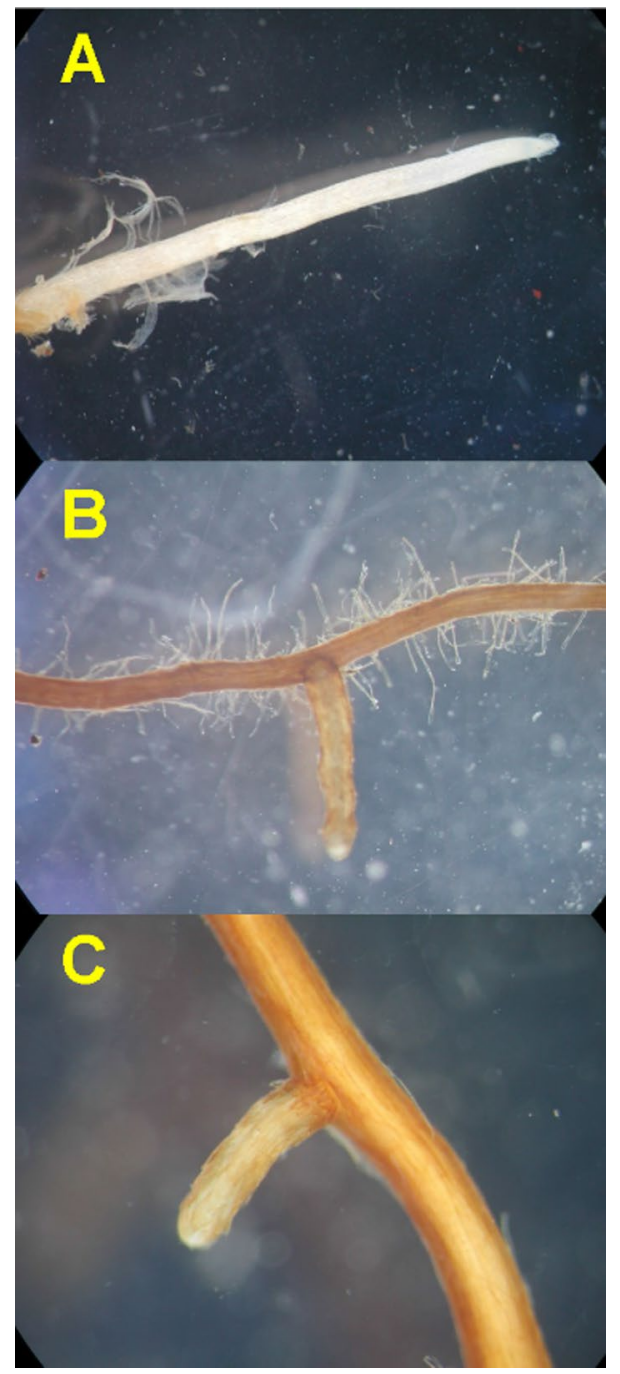

Fig. 5 Representative root with no mycorrhizae (a), root forming mycorrhizae with root hair (b) and root forming mycorrhizae without root hair (c)

\section{Leaf and root nutrient content}

Fertilizer was a significant factor for $\mathrm{Fe}, \mathrm{K}, \mathrm{Mn}, \mathrm{Na}$ and $\mathrm{Zn}$ content in the leaves and for $\mathrm{K}, \mathrm{Mn}$ and $\mathrm{P}$ content in the roots (Table 4). Leaves of seedlings grown in LF had $42.7 \%$ higher content of $\mathrm{Na}$ but $17.8 \%, 30.5 \%, 38.3 \%$, and $27.3 \%$ lower content of $\mathrm{Fe}, \mathrm{K}, \mathrm{Mn}$ and $\mathrm{Zn}$, respectively, than leaves of seedlings grown in the presence of HF (Figs. 6, 7). Roots of seedlings grown in LF had $29.5 \%, 40.2 \%$, and $20.5 \%$ lower $\mathrm{K}, \mathrm{Mn}$, and $\mathrm{P}$ content, respectively, than in roots of seedlings grown in the presence of HF (Fig. 8).

ECM was a significant factor for B content in the leaves (Table 4). Leaves of ECM-treated plants were $21.7 \%$ richer in B content than leaves of non-ECM-treated plants (Fig. 7). Ozone was a nonsignificant factor for all the nutrients (Table 4).

Fertilizer $\times \mathrm{O}_{3}$ interaction was nonsignificant for all leaf nutrients but significant for root $\mathrm{Al}$ and $\mathrm{Na}$ content; but there were no statistically significant differences when the means were tested post hoc with an $\alpha$ level Bonferroni correction (Table 4). This result suggests that any differences among means were from random variation at the tested level of significance (Fig. 9).

Fertilizer $\times \mathrm{ECM}$ interaction was significant only for leaf B content due to $49.0 \%$ greater B content in leaves of ECMtreated plants than in leaves of non-ECM-treated plants grown in $\mathrm{LF}$ (Fig. 7). $\mathrm{ECM} \times \mathrm{O}_{3}$ interaction was significant only for leaf $\mathrm{Na}$ content (Table 4), which was $50.7 \%$ lower for ECM-treated plants in EOZ than for ECM-treated plants in $\mathrm{AOZ}$ (Fig. 7). Fertilizer $\times \mathrm{ECM} \times \mathrm{O}_{3}$ interaction was nonsignificant for all nutrients in roots and leaves (Table 4). Al, $\mathrm{Co}$ and $\mathrm{P}$ content in the leaves and of $\mathrm{B}, \mathrm{Fe}$ and $\mathrm{Zn}$ content in the root did not differ significantly among treatments (Supplementary Materials, Figs. S4, S5).
Table 3 Means \pm SE of production traits of Japanese larch seedlings grown in low fertilization (LF) and treated with ectomycorrhizae and no fungicide (ECM) or sterilized water and fungicide (non-ECM) and exposed to ambient (AOZ) or elevated (EOZ) ozone

\begin{tabular}{lllll}
\hline Trait & $\mathrm{ECM} \times \mathrm{AOZ}$ & $\mathrm{ECM} \times \mathrm{EOZ}$ & Non-ECM $\times \mathrm{AOZ}$ & Non-ECM $\times \mathrm{EOZ}$ \\
\hline Nonmycorrhizal & $47.0^{\mathrm{a}} \pm 4.6$ & $80.3^{\mathrm{a}} \pm 26.0$ & $54.5^{\mathrm{a}} \pm 15.6$ & $10.3^{\mathrm{b}} \pm 3.8$ \\
Forming mycorrhiza & $1315.7 \pm 55.1$ & $1036.0 \pm 87.4$ & $763.0 \pm 153.5$ & $523.0 \pm 181.2$ \\
No root tips & $49.0^{\mathrm{ab}} \pm 7.5$ & $90.0^{\mathrm{a}} \pm 18.7$ & $46.0^{\mathrm{bc}} \pm 11.4$ & $20.3^{\mathrm{c}} \pm 5.3$ \\
Total root tips & $1411.7 \pm 67.3$ & $1206.3 \pm 109.9$ & $863.5 \pm 177.8$ & $553.5 \pm 187.5$ \\
Results of $G L M$ & & & & \\
& Nonmycorrhizal & Forming mycorrhiza & No root tips & Total root tips \\
ECM & $\boldsymbol{F}=\mathbf{6 . 1 9}, \boldsymbol{P}<\mathbf{0 . 0 5}$ & $\boldsymbol{F}=\mathbf{1 3 . 6 8}, \boldsymbol{P}<\mathbf{0 . 0 1}$ & $\boldsymbol{F}=\mathbf{1 0 . 7 9}, \boldsymbol{P}<\mathbf{0 . 0 1}$ & $\boldsymbol{F}=\mathbf{1 4 . 5}, \boldsymbol{P}<\mathbf{0 . 0 1}$ \\
$\mathrm{O}_{3}$ & $F=1.53, P=0.245$ & $F=3.28, P=0.100$ & $F<0.01, P=0.926$ & $F=2.64, P=0.135$ \\
$\mathrm{ECM} \times \mathrm{O}_{3}$ & $\boldsymbol{F}=\mathbf{7 . 0 1}, \boldsymbol{P}<\mathbf{0 . 0 5}$ & $F=0.05, P=0.826$ & $\boldsymbol{F}=\mathbf{7 . 9 4}, \boldsymbol{P}<\mathbf{0 . 0 5}$ & $F=0.05, P=0.831$ \\
\hline
\end{tabular}

Traits assessed: total number of nonmycorrhizal roots (nonmycorrhizal), total number of root tips with forming mycorrhiza (forming mycorrhiza), total number of roots with no root tip or aerial cut of root tip (no root tips) and total number of root tips. Different letters after means indicate statistically significant differences according to Bonferroni test. Results in bold indicate statistical significance according to generalized linear model (GLM) testing 
Table 4 Statistical results for comparison of nutrient levels in leaves and roots

\begin{tabular}{|c|c|c|c|c|c|c|c|}
\hline Leaves & Fertilizer & ECM & $\mathrm{O}_{3}$ & Fertilizer $\times \mathrm{O}_{3}$ & Fertilizer $\times \mathrm{ECM}$ & $\mathrm{ECM} \times \mathrm{O}_{3}$ & $\begin{array}{l}\text { Ferti- } \\
\text { lizer } \times \mathrm{ECM} \times \mathrm{O}_{3}\end{array}$ \\
\hline $\mathrm{Al}$ & $\begin{array}{l}F=0.01, \\
P=0.912\end{array}$ & $\begin{array}{l}F=1.33 \\
P=0.266\end{array}$ & $\begin{array}{l}F=0.74 \\
P=0.401\end{array}$ & $\begin{array}{l}F=1.33 \\
P=0.265\end{array}$ & $\begin{array}{l}F=0.84, \\
P=0.372\end{array}$ & $\begin{array}{l}F=0.01, \\
P=0.928\end{array}$ & $F=0.37, P=0.554$ \\
\hline B & $\begin{array}{l}F=0.02, \\
P=0.832\end{array}$ & $\begin{array}{r}F=6.86 \\
P<0.05\end{array}$ & $\begin{array}{l}F=0.40 \\
P=0.535\end{array}$ & $\begin{array}{l}F=1.09 \\
P=0.311\end{array}$ & $\begin{aligned} F=6.48 \\
P<0.05^{\mathrm{a}}\end{aligned}$ & $\begin{array}{c}F=2.16 \\
P=0.161\end{array}$ & $F=1.84, P=0.194$ \\
\hline $\mathrm{Ca}$ & $\begin{array}{l}F=1.45 \\
P=0.246\end{array}$ & $\begin{array}{l}F=1.09 \\
P=0.312\end{array}$ & $\begin{array}{l}F=0.02, \\
P=0.892\end{array}$ & $\begin{array}{l}F=0.16 \\
P=0.695\end{array}$ & $\begin{array}{l}F=0.06 \\
P=0.817\end{array}$ & $\begin{array}{l}F=0.14 \\
P=0.713\end{array}$ & $F=0.41, P=0.533$ \\
\hline $\mathrm{Fe}$ & $\begin{aligned} F & =4.84 \\
P & <0.05\end{aligned}$ & $\begin{array}{l}F=1.15, \\
P=0.299\end{array}$ & $\begin{array}{l}F=0.21 \\
P=0.650\end{array}$ & $\begin{array}{l}F=0.47 \\
P=0.501\end{array}$ & $\begin{array}{l}F=1.50 \\
P=0.239\end{array}$ & $\begin{array}{l}F=0.49 \\
P=0.494\end{array}$ & $F=0.25, P=0.621$ \\
\hline K & $\begin{array}{r}F=4.41 \\
P=0.05\end{array}$ & $\begin{array}{l}F=1.90 \\
P=0.187\end{array}$ & $\begin{array}{l}F=1.94 \\
P=0.183\end{array}$ & $\begin{array}{l}F=0.50 \\
P=0.491\end{array}$ & $\begin{array}{l}F=0.55 \\
P=0.471\end{array}$ & $\begin{array}{l}F=0.01 \\
P=0.910\end{array}$ & $F=0.02, P=0.894$ \\
\hline $\mathrm{Mg}$ & $\begin{array}{l}F<0.01 \\
P=0.983\end{array}$ & $\begin{array}{l}F=0.09 \\
P=0.772\end{array}$ & $\begin{array}{l}F=0.01, \\
P=0.925\end{array}$ & $\begin{array}{l}F=0.16 \\
P=0.698\end{array}$ & $\begin{array}{l}F=0.03 \\
P=0.877\end{array}$ & $\begin{array}{l}F=0.07 \\
P=0.794\end{array}$ & $F=1.78, P=0.201$ \\
\hline $\mathrm{Mn}$ & $\begin{array}{r}F=8.71 \\
P<0.01\end{array}$ & $\begin{array}{l}F=2.50, \\
P=0.134\end{array}$ & $\begin{array}{l}F=0.48 \\
P=0.499\end{array}$ & $\begin{array}{l}F<0.01 \\
P=0.970\end{array}$ & $\begin{array}{l}F=0.11 \\
P=0.746\end{array}$ & $\begin{array}{l}F=3.14 \\
P=0.096\end{array}$ & $F=0.24, P=0.631$ \\
\hline $\mathrm{Na}$ & $\begin{array}{r}F=4.40 \\
P=0.05\end{array}$ & $\begin{array}{l}F=1.00 \\
P=0.333\end{array}$ & $\begin{array}{l}F=4.05 \\
P=0.061\end{array}$ & $\begin{array}{l}F=1.77, \\
P=0.202\end{array}$ & $\begin{array}{l}F=0.37 \\
P=0.551\end{array}$ & $\begin{array}{c}F=5.02 \\
P<0.05^{\mathrm{b}}\end{array}$ & $F=0.44, P=0.519$ \\
\hline $\mathrm{P}$ & $\begin{array}{l}F=0.43 \\
P=0.522\end{array}$ & $\begin{array}{l}F=0.03 \\
P=0.891\end{array}$ & $\begin{aligned} F= & 2.33 \\
P & =0.146\end{aligned}$ & $\begin{array}{l}F=2.34 \\
P=0.145\end{array}$ & $\begin{array}{l}F=0.26 \\
P=0.615\end{array}$ & $\begin{array}{l}F=0.07 \\
P=0.793\end{array}$ & $F=0.19, P=0.672$ \\
\hline $\mathrm{Zn}$ & $\begin{array}{r}F=5.40 \\
P<0.05\end{array}$ & $\begin{array}{l}F=1.10 \\
P=0.310\end{array}$ & $\begin{array}{l}F=0.88 \\
P=0.363\end{array}$ & $\begin{aligned} F & <0.01 \\
P & =0.993\end{aligned}$ & $\begin{array}{l}F=0.18 \\
P=0.682\end{array}$ & $\begin{array}{l}F=0.72, \\
P=0.408\end{array}$ & $F<0.01, P=0.985$ \\
\hline \multicolumn{8}{|l|}{ Roots } \\
\hline Al & $\begin{array}{l}F=1.36 \\
P=0.262\end{array}$ & $\begin{array}{l}F=0.77 \\
P=0.393\end{array}$ & $\begin{array}{l}F=0.29 \\
P=0.598\end{array}$ & $\begin{aligned} F & =8.23 \\
P & <0.05^{\mathrm{c}}\end{aligned}$ & $\begin{array}{l}F=0.04 \\
P=0.847\end{array}$ & $\begin{array}{l}F=0.05 \\
P=0.819\end{array}$ & $F=0.24, P=0.631$ \\
\hline B & $\begin{array}{l}F=1.13 \\
P=0.304\end{array}$ & $\begin{array}{l}F=0.05 \\
P=0.831\end{array}$ & $\begin{array}{l}F=1.63 \\
P=0.220\end{array}$ & $\begin{array}{l}F=2.32 \\
P=0.147\end{array}$ & $\begin{array}{l}F=0.14 \\
P=0.715\end{array}$ & $\begin{array}{l}F=0.42, \\
P=0.526\end{array}$ & $F=0.14, P=0.718$ \\
\hline $\mathrm{Ca}$ & $\begin{array}{l}F=0.34 \\
P=0.570\end{array}$ & $\begin{array}{l}F=0.53 \\
P=0.478\end{array}$ & $\begin{array}{l}F=0.03 \\
P=0.862\end{array}$ & $\begin{array}{l}F=1.19 \\
P=0.291\end{array}$ & $\begin{array}{l}F=0.09 \\
P=0.764\end{array}$ & $\begin{array}{l}F=0.03 \\
P=0.871\end{array}$ & $F=0.82, P=0.379$ \\
\hline $\mathrm{Fe}$ & $\begin{array}{l}F=0.32 \\
P=0.578\end{array}$ & $\begin{array}{l}F=0.25, \\
P=0.622\end{array}$ & $\begin{aligned} F=3.17 \\
P=0.094\end{aligned}$ & $\begin{aligned} F= & 2.31, \\
P & =0.148\end{aligned}$ & $\begin{array}{l}F=0.13, \\
P=0.725\end{array}$ & $\begin{aligned} F & =0.52, \\
P & =0.235\end{aligned}$ & $F=3.59, P=0.077$ \\
\hline K & $\begin{array}{r}F=7.18, \\
P<0.05\end{array}$ & $\begin{array}{l}F=0.92, \\
P=0.351\end{array}$ & $\begin{aligned} F= & 0.97 \\
P & =0.340\end{aligned}$ & $\begin{array}{c}F=1.62, \\
P=0.221\end{array}$ & $\begin{array}{c}F=0.39 \\
P=0.541\end{array}$ & $\begin{aligned} F= & 0.39 \\
P & =0.539\end{aligned}$ & $F<0.01, P=0.221$ \\
\hline $\mathrm{Mg}$ & $\begin{array}{l}F=0.84 \\
P=0.373\end{array}$ & $\begin{array}{l}F=0.11, \\
P=0.750\end{array}$ & $\begin{array}{l}F=1.83 \\
P=0.195\end{array}$ & $\begin{array}{l}F=1.15 \\
P=0.299\end{array}$ & $\begin{array}{l}F=0.05 \\
P=0.832\end{array}$ & $\begin{array}{l}F=0.25 \\
P=0.626\end{array}$ & $F=0.48, P=0.498$ \\
\hline $\mathrm{Mn}$ & $\begin{array}{r}F=10.80 \\
P<0.01\end{array}$ & $\begin{array}{l}F=1.97 \\
P=0.180\end{array}$ & $\begin{array}{l}F=0.97 \\
P=0.339\end{array}$ & $\begin{array}{l}F=1.74 \\
P=0.206\end{array}$ & $\begin{array}{l}F=1.90 \\
P=0.187\end{array}$ & $\begin{aligned} & F<0.01 \\
& P=0.927\end{aligned}$ & $F=0.04, P=0.850$ \\
\hline $\mathrm{Na}$ & $\begin{array}{l}F=1.36 \\
P=0.260\end{array}$ & $\begin{aligned} F= & 0.59, \\
P & =0.454\end{aligned}$ & $\begin{array}{l}F=0.18 \\
P=0.680\end{array}$ & $\begin{aligned} F & =7.36, \\
P & <0.05^{\mathrm{c}}\end{aligned}$ & $\begin{aligned} & F<0.01 \\
& P=0.958\end{aligned}$ & $\begin{array}{l}F=4.16, \\
P=0.058\end{array}$ & $F<0.01, P=0.932$ \\
\hline $\mathrm{P}$ & $\begin{array}{r}F=4.65 \\
P<0.05\end{array}$ & $\begin{array}{l}F=1.50, \\
P=0.238\end{array}$ & $\begin{aligned} F= & 0.84 \\
P & =0.375\end{aligned}$ & $\begin{array}{l}F=0.17 \\
P=0.682\end{array}$ & $\begin{array}{l}F=0.20 \\
P=0.659\end{array}$ & $\begin{array}{c}F=0.30 \\
P=0.590\end{array}$ & $F=0.12, P=0.732$ \\
\hline $\mathrm{Zn}$ & $\begin{array}{l}F=1.58 \\
P=0.226\end{array}$ & $\begin{array}{l}F=0.03, \\
P=0.870\end{array}$ & $\begin{array}{l}F=0.98 \\
P=0.337\end{array}$ & $\begin{array}{l}F=0.29, \\
P=0.598\end{array}$ & $\begin{aligned} F=0.33 \\
P=0.576\end{aligned}$ & $\begin{array}{l}F=0.04, \\
P=0.852\end{array}$ & $F=3.14, P=0.095$ \\
\hline
\end{tabular}

Data were tested using a generalized linear model at $\alpha=0.05$. Values in bold indicate statistical significance. Data are presented in Figs. $6,7,8$ and 9 or in Supplementary Materials (for those with no statistical significance)

${ }^{a}$ The only significance difference was between non-ECM-treated and ECM-treated plants grown in LF (Bonferroni)

${ }^{b}$ The only significance difference was between ECM-treated plants in AOZ and ECM-treated plants in EOZ (Bonferroni). ${ }^{\mathrm{c}}$ There was no statistically significant difference when the means were tested post hoc with $a$ level Bonferroni correction

\section{Survival rate}

For survival rate of seedlings, damping off symptoms affected $52.4 \pm 4.1 \%$ of HF plants and $88.1 \pm 3.0 \%$ of LF plants, representing a significant difference $(F=51.7$, $P<0.001)$.

\section{Discussion}

\section{Fertilization}

Although fertilizer treatment did not affect gas exchange, plants grown in the presence of HF were taller and had 
Fig. 6 Means $\pm \operatorname{SE}(n=3)$ for leaf nutrient content in Japanese larch seedlings grown in two soil fertilization regimes, treated with ectomycorrhizae and no fungicide (ECM) or sterilized water and fungicide (non-ECM) and exposed to ambient (AOZ) or elevated (EOZ) ozone $\left(\mathrm{O}_{3}\right)$. An asterisk indicates significant single effect and "ns" indicates nonsignificant single effect, within a response variable, according to a generalized linear model at $\alpha=0.05$. No interactions were significant
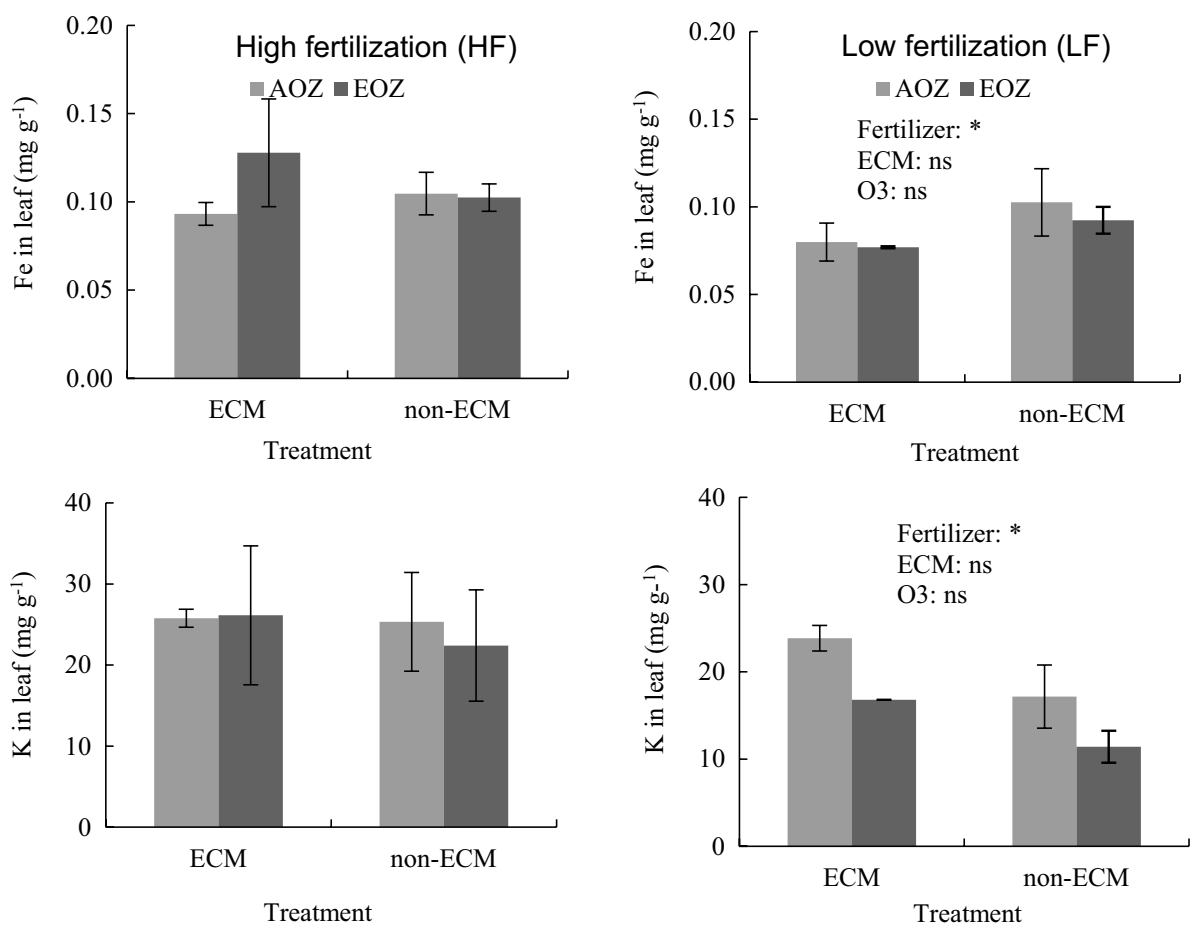

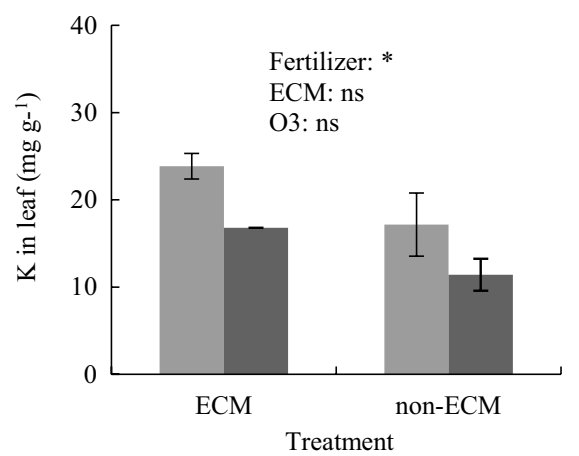

thicker stems and deeper, wider crowns than plants grown in LF. This growth enhancement did not translate to a significant gain in biomass production (despite the large arithmetic differences), because of the high variance that was likely generated by the limiting growing conditions (see next section). However, plants grown in the presence of HF had a significant gain in terms of reproductive capacity as indicated by more buds compared to plants grown in LF. The ratios of buds to root dry matter and f buds to total dry matter were not affected by HF, so there was no imbalance between reproduction and biomass productivity.

Fertilizer treatment drove nutrient dynamics in leaves and roots. Leaves of seedlings grown in LF had higher $\mathrm{Na}$ content than in those grown in the presence of HF, even if the content in the roots was not significantly different. The harsh conditions for the plants grown in LF may induce oxidative stress due to nutrient deficiency. The increase in $\mathrm{Na}$ content may be attributed to $\mathrm{K}$ deficiency and a need of plants grown in LF to account for $\mathrm{K}^{+}$deficiency by increasing $\mathrm{Na}^{+}$, as both elements have similar efficacy in several functions (Maathuis 2014). The substitution of $\mathrm{K}$ by $\mathrm{Na}$ is well known and understood, and can occur in a wide array of plants. However, growth stimulation by $\mathrm{Na}$, mainly via water balance and cell expansion, is also possible, as $\mathrm{Na}$ has a better osmotic adjustment and may contribute better to the solute potential in the vacuoles than $\mathrm{K}$.
$\mathbf{O}_{3}$

Gas exchange results suggested than EOZ induced uncoupling between $A_{390}$ and $\mathrm{Gs}_{390}$. Such an $\mathrm{O}_{3}$-induced photosynthesis-conductance uncoupling was found in previous experiments with trees as well as crop plants (Tjoelker et al. 1995; Calatayud et al. 2007; Francini et al. 2007; Singh et al. 2009) and may indicate that the reduction in $A_{390}$ was due to some extent to factors other than a reduced $\mathrm{Gs}_{390}$. Although $A_{390}$ was affected by EOZ, the response to light was not significantly affected, suggesting that EOZ-treated plants could reduce $\mathrm{Gs}_{390}$ and $A_{390}$ to the same extend with $\mathrm{AOZ}$ plants within a time window of $15 \mathrm{~min}$. While elevated $\mathrm{O}_{3}$ can induce stomatal sluggishness and decelerate the response to light (Paoletti 2005; Hoshika et al. 2013), our results suggest that EOZ did not cause a permanent impairment in stomata/photosynthesis response to light (delayed or sluggish response was not studied in this experiment). This may be attributed to no EOZ-induced inhibition of guard cell $\mathrm{K}^{+}$ channels that control stomata (Torsethaugen et al. 1999); EOZ did not alter $\mathrm{K}$ content in the leaves. The reduction in $A_{390}$ may relate to the smaller crown span and stem diameter that were caused by EOZ. Elevated $\mathrm{O}_{3}$ can alter nutrient composition, affect allocation to different organs, and have impacts in ecological stoichiometry of trees ( $\mathrm{Li}$ et al. 2017a; Shang et al. 2018, 2019). However, in this study, the only significant effect of $\mathrm{O}_{3}$ on leaf nutrients content was for $\mathrm{Na}$ content in ECM-treated plants grown in EOZ, which was approximately half of that in ECM-treated plants grown in 
Fig. 7 Mean \pm SE $(n=3)$ leaf nutrient content in Japanese larch seedlings grown in two soil fertilization regimes, treated with ectomycorrhizae and no fungicide (ECM) or sterilized water and fungicide (non-ECM) and exposed to ambient (AOZ) or elevated (EOZ) ozone $\left(\mathrm{O}_{3}\right)$. An asterisk indicates significant single effect and "ns" indicates nonsignificant single effect, within a response variable, according to a generalized linear model at $\alpha=0.05$. The only significant (Bonferroni post hoc test) interactions were $\mathrm{ECM} \times \mathrm{O}_{3}$ for $\mathrm{Na}$ (only between ECM-treated plants in $\mathrm{AOZ}$ and ECM-treated plants in EOZ) and Fertilizer $\times$ ECM for B (only between non-ECM-treated and ECM-treated plants grown in LF)
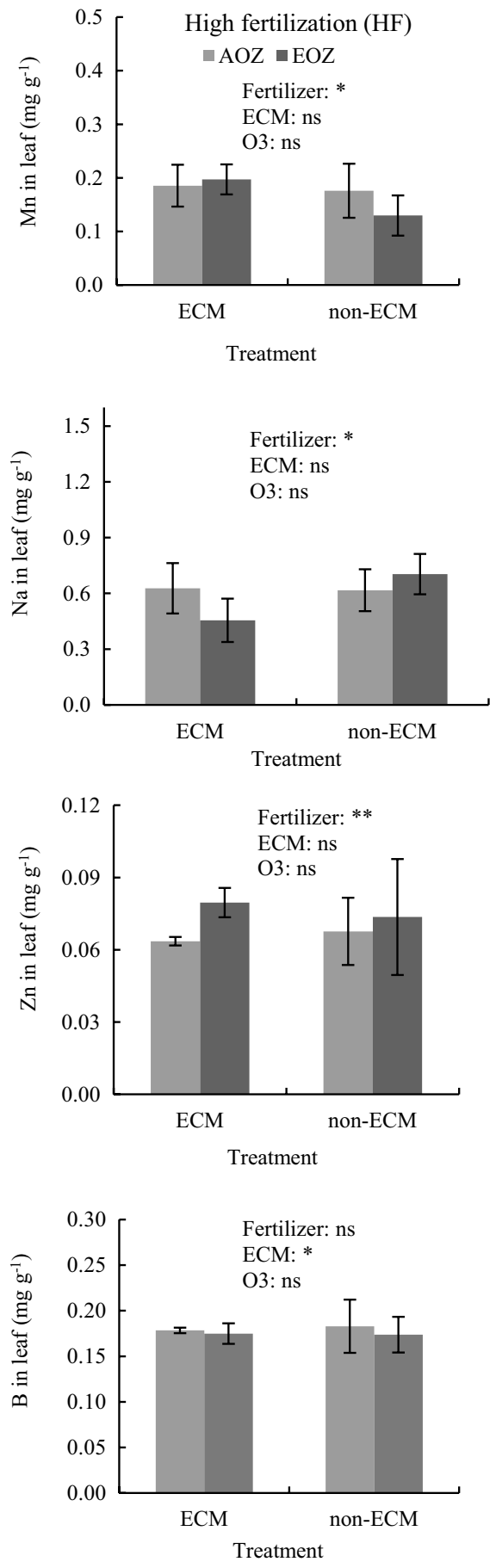
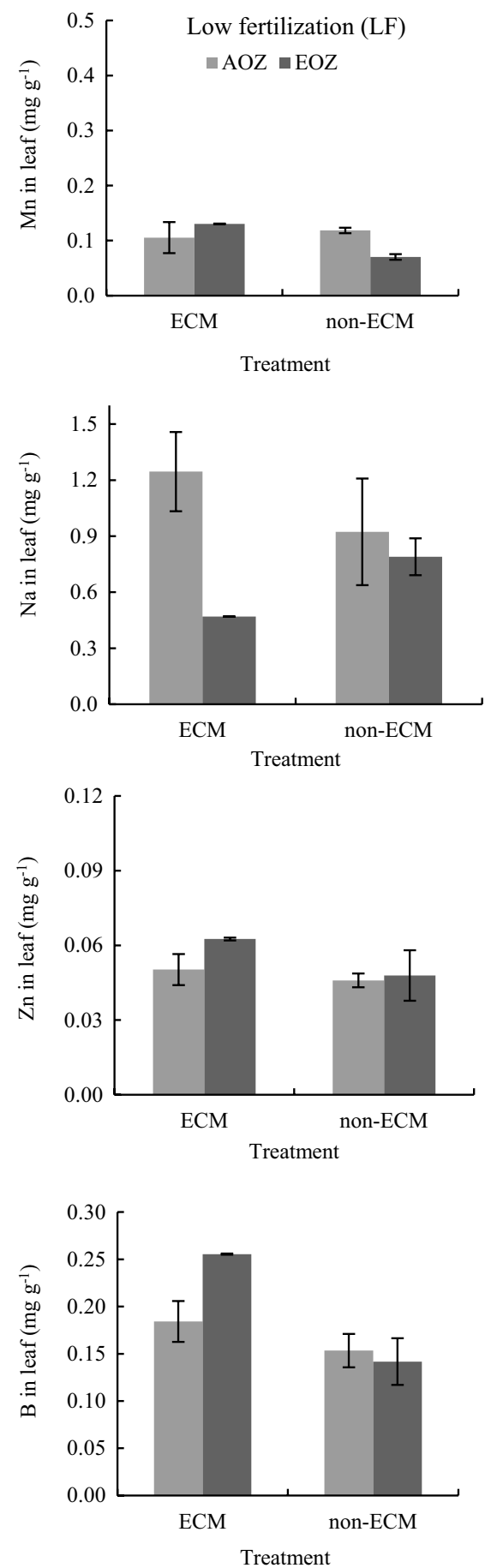

AOZ. These suggest that Na had a major role (among all leaf nutrients analyzed) in the plant response to the combined effect of EOZ and root colonizers. However, the change in Na could not be linked with any of the physiological traits analyzed.

The fact that EOZ decreased stem diameter but did not reduce stem height may indicate an altered stem shape with potentially higher susceptibility of larches to other stressors such as strong winds (Agathokleous et al. 2017; Watanabe et al. 2013). Interestingly, EOZ increased the root length in spite of lower $A_{390}$, an observation that may indicate that EOZ-induced stress was modest rather than adverse (Agathokleous et al. 2019).

The overly small size of plants across experimental conditions (treatments) suggests that all plants were stressed by factors other than those experimentally manipulated. In this experiment, plants were grown in cocopeat substrate whose physical properties drive air capacity and water 
Fig. 8 Mean \pm SE $(n=3)$ root nutrient content in Japanese larch seedlings grown in two soil fertilization regimes, treated with ectomycorrhizae and no fungicide (ECM) or sterilized water and fungicide (non-ECM) and exposed to ambient (AOZ) or elevated (EOZ) ozone $\left(\mathrm{O}_{3}\right)$. An asterisk indicates significant single effect and "ns" indicates nonsignificant single effect, within a response variable, according to a generalized linear model at $\alpha=0.05$. No interactions were significant (Bonferroni post hoc test)
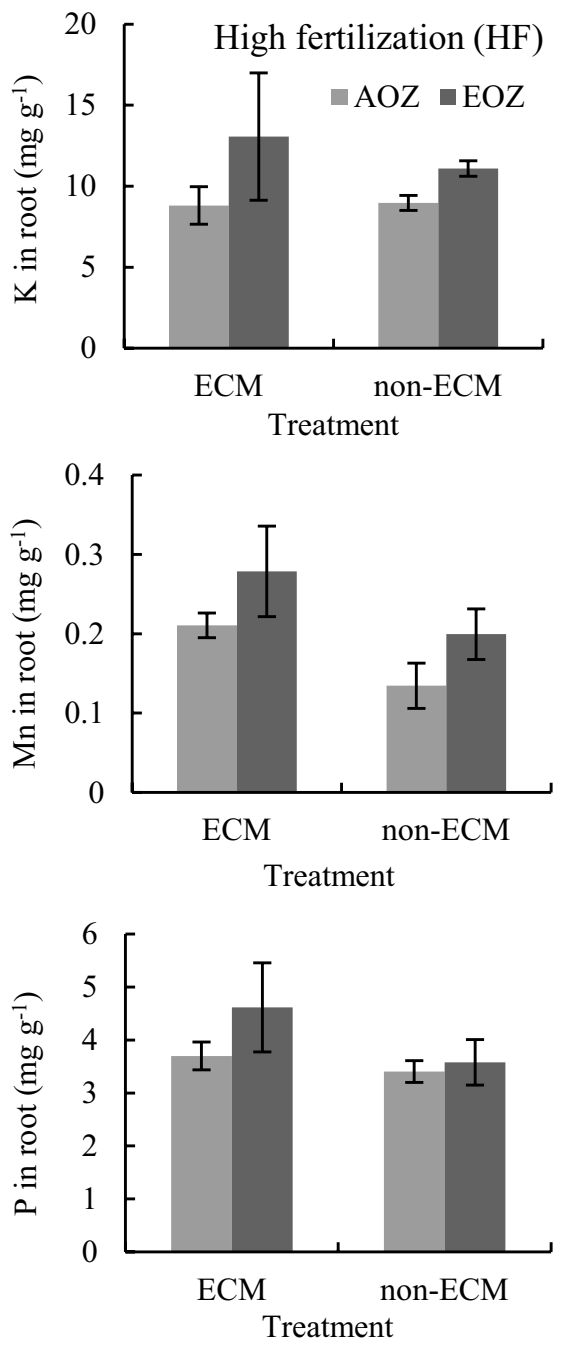
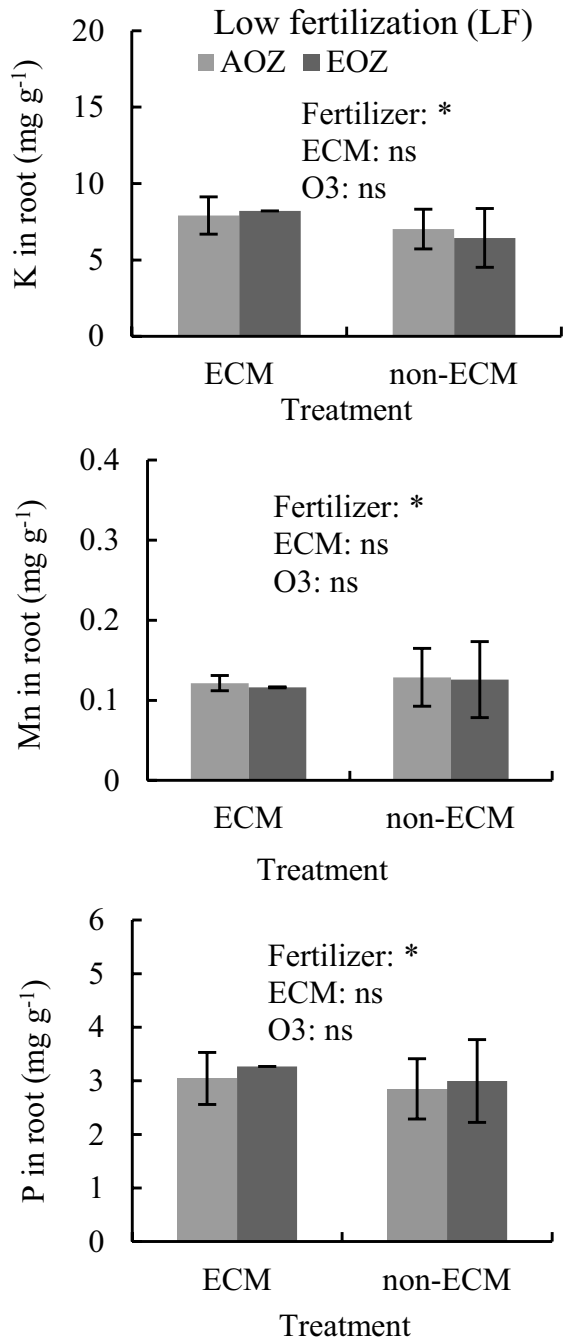

retention (Abad et al. 2002). Cocopeat has a high waterholding capacity and poor aeration, which affects $\mathrm{O}_{2}$ diffusion to the roots (Awang et al. 2009). These characteristics of the soil substrate used may explain why plant growth was restricted even for plants grown in HF. Based on findings on the effects of $\mathrm{CO}_{2}$ on plants, plant-soil coupling deserves more attention than plant-atmosphere coupling (Körner 2006); that is, the control over plants is far stronger for soil than for atmospheric conditions. Experiments studying the effects of $\mathrm{O}_{3}$ on plants have been principally done with healthy/vigorous plants grown under optimum conditions, yet plants will rarely, if ever, grow under such conditions in the real world. Thus, $\mathrm{O}_{3}$ effects on plants may be overestimated (Körner 2006). Previous experiments with vigorous plants grown in optimum or near-optimum conditions in the same experimental forest suggested significant effects of $\mathrm{O}_{3}$ (concentrations similar to those used here) on growth and biomass production of Japanese larch seedlings and tall saplings (Agathokleous et al. 2017; Sugai et al. 2019). Conversely, the present results, from an experiment with plants with limited vigor, revealed only limited effects on gas exchange and nearly no effects on leaf and root nutrient content, growth and biomass production. A recent study with poplars also found that the decrease in plant biomass induced by elevated $\mathrm{O}_{3}$ was limited when water and nutrients in the soil were limiting factors (Li et al. 2019b).

\section{ECM treatment}

The smaller diameter unaccompanied by a smaller height in ECM-treated plants, compared to non-ECM-treated plants, also suggests an altered stem shape, indicative of stress, as it was observed with $\mathrm{O}_{3}$. There were no significant differences between ECM-treated and non-ECM-treated plants as to gas exchange physiology, growth, and productivity, except a higher $E_{390}$ in ECM-treated plants than in nonECM plants when grown in LF. The higher $E_{390}$ may be due to more acquisition of water in ECM-treated plants in LF (Birhane et al. 2012). Transpiration was shown before to increase in plants highly infected with root microbes (Drüge 
Fig. 9 Mean \pm SE $(n=3)$ root nutrient levels in Japanese larch seedlings grown in two soil fertilization regimes, treated with ectomycorrhizae and no fungicide $(\mathrm{ECM})$ or sterilized water and fungicide (non-ECM) and exposed to ambient (AOZ) or elevated (EOZ) ozone $\left(\mathrm{O}_{3}\right)$. "ns" indicates nonsignificant single effect, within a response variable, according to a generalized linear model at $\alpha=0.05$. There was no significant difference in multiple comparisons for the interactions (Bonferroni post hoc test; Table 4)
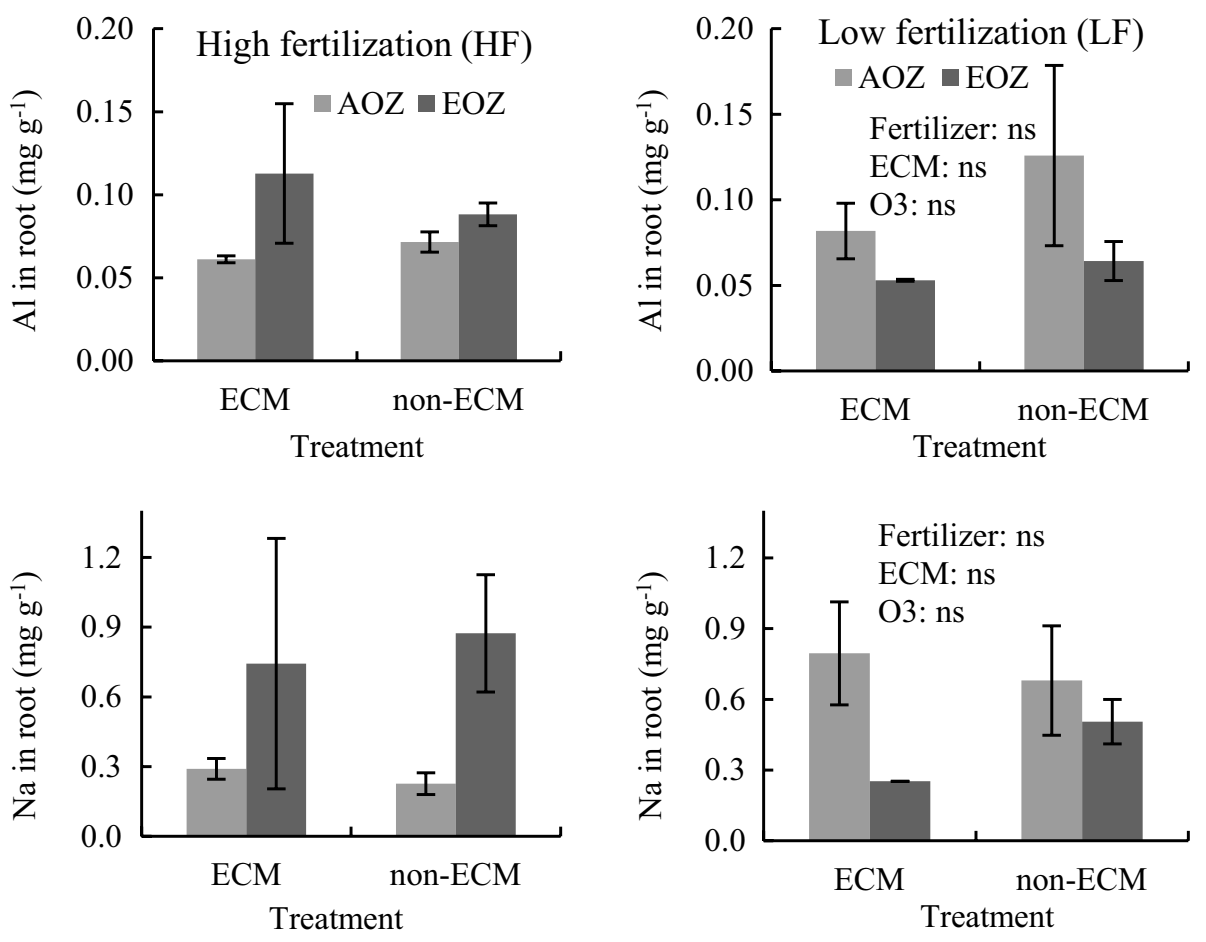

and Schonbeck 1993), an effect which likely depends on the soil water potential (Bingyun and Nioh 1997).

A following analysis of root traits in plants grown in LF revealed that inoculation of plants with ECM (ECMtreated) was successful in inducing an increase in the mycorrhizal roots. However, it is noteworthy that there were only incomplete mycorrhizal roots with no mantle and no complete mycorrhizal roots, suggesting that the development of mycorrhizal roots initiated but for some reason could not be completed. The reason cannot be confirmed, but we can speculate that the seedlings were too young or small for complete formation of mycorrhizal roots. Further DNA analyses revealed that ECM-treated plants were infected with only Fusarium sp. and non-treated ones were infected with Suillus grevillei (larch-specific ECM; Wang et al. 2015) and Dothideomycetes sp. (endophytic mycorrhiza).These results suggest that non-ECM-treated plants were infected normally with (ecto)mycorrhizae that can be transferred through aerial spores and that the control of damping-off was effective. On the other hand, surprisingly, no mycorrhizae could be identified in roots of ECM-treated plants. Furthermore, Fusarium sp. was identified, which may be responsible for the damping-off (Seseni et al. 2015), a worldwide disease caused by soil-borne pathogens that rots seedlings (Lamichhane et al. 2017). The conditions in the cocopeat substrate (Abad et al. 2002; Awang et al. 2009; see also section 4.2), might have contributed to the development of damping off. Since seeds were treated against potential infection, the entry of pathogens into the system was not via chamydospores in the seeds but likely via aerial transfer. Considering that ECM-treated plants were not treated against damping off, the presence of only Fusarium sp. and the existence of a higher number of mycorrhizal roots (compared to non-ECM-treated plants) may indicate that Fusarium sp. replaced (ecto) mycorrhizae. The results also showed that 9 of 10 seedlings survived damping-off when grown in LF; however, only 5 of 10 seedlings survived when grown in the presence of HF, suggesting that low nutrient availability may mitigate the disease at some extend. These findings offer an important perspective for management practices.

In this experiment with plants stressed by factors other than root colonizers, root colonizers had no effect on leaf nutrient content, except more B in leaves of ECM-treated plants than in leaves of non-ECM-treated plants grown in LF. This increase in B content may be part of a defense mechanism of plants against Fusarium sp. for reducing or controlling disease severity (Dong et al. 2016; Jiang et al. 2016) and suggests a potentially important role for $\mathrm{B}$ in reducing disease development (Chappelka and Grulke 2016). Further studies should assess the role of B in stress and disease biology over time and for different experimental setups to confirm that its role in a stress-defense mechanism.

\section{Conclusions}

The interactive effects of $\mathrm{O}_{3}$, soil substrate fertilization and root colonizers were investigated for the first time in Japanese container-grown seedlings. Soil fertilization status drove plant nutrient dynamics, as reflected in their contents 
in leaves and roots, and enhanced seedling growth. Low nutrient availability protected seedlings against damping off by increasing their survival rate.

EOZ negatively affected gas exchange but had no effects on growth (except an increase in root length) and biomass production. $\mathrm{O}_{3}$ was a minor stressor in this experiment where seedling growth and productivity was restricted by factors other than $\mathrm{O}_{3}$ (soil and microorganisms). Nonetheless, the results suggest potential ecological risks due to elevated $\mathrm{O}_{3}$-induced enhanced susceptibility to other stressors via changes in the form of plant stem, even under conditions where factors other than $\mathrm{O}_{3}$ dominate plant health/stress.

In contrast to our expectations, ECM treatment did not enhance the tolerance of plants against elevated $\mathrm{O}_{3}$, albeit it effectively increased the number of (mycorrhiza-forming) root tips. However, this is due to practical limitations arising from the effects of disease and other factors that might have affected the establishment of plant-microbe symbioses and the formation of complete mycorrhizal root tips (e.g., small plant size). Nonetheless, this research provides an important basis for designing relevant studies in the future.

Fungal root colonizers and fertilization had no significant interactive effects with $\mathrm{O}_{3}$ in this experiment. $\mathrm{B}$ and $\mathrm{Na}$, among 10 nutrients analyzed, seem to have an important role in stress responses. Further studies are needed to reveal potential physiological mechanisms linked to the regulation of $\mathrm{B}$ and $\mathrm{Na}$. We conclude that elevated $\mathrm{O}_{3}$ can have negative ecological effects on Japanese larch even if plants are grown in a harsh environment where factors other than $\mathrm{O}_{3}$ may strongly limit plant growth and productivity.

Acknowledgements The authors are grateful to Mr. Tatsushiro Ueda of Dalton Co. (Hokkaido Branch, Japan) for managing the $\mathrm{O}_{3} \mathrm{FACE}$ system and to Mr. Yamamoto and Mr. Noda of Hokkaido University, Japan, for contributing to the ectomycorrhizae analysis. E. A. acknowledges multiyear support from The Startup Foundation for Introducing Talent of Nanjing University of Information Science \& Technology (NUIST), Nanjing, China (Grant No. 1411021901008). This study was presented in part by E. A. at the 65th Annual Meeting of the Ecological Society of Japan, 14-18 March 2018, Sapporo, Japan; the workshop "Agriculture and Animal Husbandry in a Changing Climate", 16-17 May 2018, Nicosia, Cyprus; the International Conference on Ozone and Plant Ecosystems, 21-25 May 2018, Florence, Italy; and the conference "Forests and Health and Forum for Under-Forestry Economic Industry", 2-5 August 2018, Harbin, P. R. China.

Open Access This article is distributed under the terms of the Creative Commons Attribution 4.0 International License (http://creativeco mmons.org/licenses/by/4.0/), which permits unrestricted use, distribution, and reproduction in any medium, provided you give appropriate credit to the original author(s) and the source, provide a link to the Creative Commons license, and indicate if changes were made.

\section{References}

Abad M, Noguera P, Puchades R, Maquieira A, Noguera V (2002) Physico-chemical and chemical properties of some coconut coir dusts for use as a peat substitute for containerised ornamental plants. Bioresour Technol 82:241-245

Agathokleous E, Saitanis CJ, Stamatelopoulos D, Mouzaki-Paxinou A-C, Paoletti E, Manning WJ (2016a) Olive oil for dressing plant leaves so as to avoid $\mathrm{O}_{3}$ injury. Water Air Soil Pollut 227:282

Agathokleous E, Saitanis CJ, Wang X, Watanabe M, Koike T (2016b) A review study on past 40 years of research on effects of tropospheric $\mathrm{O}_{3}$ on belowground structure, functioning, and processes of trees: a linkage with potential ecological implications. Water Air Soil Pollut 227:33

Agathokleous E, Vanderstock A, Kita K, Koike T (2017) Stem and crown growth of Japanese larch and its hybrid $\mathrm{F}_{1}$ grown in two soils and exposed to two free-air $\mathrm{O}_{3}$ regimes. Environ Sci Pollut Res 24:6634-6647

Agathokleous E, Belz RG, Kitao M, Koike T, Calabrese EJ (2019) Does the root to shoot ratio show a hormetic response to stress? An ecological and environmental perspective. J For Res 30:1569-1580

Ainsworth EA, Yendrek CR, Sitch S, Collins WJ, Emberson LD (2012) The effects of tropospheric ozone on net primary productivity and implications for climate change. Annu Rev Plant Biol 63:637-661

Akimoto H (2003) Global air quality and pollution. Science 302:1716-1719

Akimoto H, Mori Y, Sasaki K, Nakanishi H, Ohizumi T, Itano Y (2015) Analysis of monitoring data of ground-level ozone in Japan for long-term trend during 1990-2010: causes of temporal and spatial variation. Atmos Environ 102:302-310

Awang Y, Shaharom AS, Mohamad RB, Selamat A, Awang Y, Shaharom AS, Mohamad RB, Selamat A (2009) Chemical and physical characteristics of cocopeat-based media mixtures and their effects on the growth and development of Celosia cristata. Am J Agric Biol Sci 4:63-71

Bielenberg DG, Lynch JP, Pell EJ (2001) A decline in nitrogen availability affects plant responses to ozone. New Phytol 151:413-425

Bingyun W, Nioh I (1997) Growth and water relations of P. tabulaeformis seedlings inoculated with ectomycorrhizal fungi. Microbes Environ 12:69-74

Birhane E, Sterck FJ, Fetene M, Bongers F, Kuyper TW (2012) Arbuscular mycorrhizal fungi enhance photosynthesis, water use efficiency, and growth of frankincense seedlings under pulsed water availability conditions. Oecologia 169:895-904

Blande JD, Holopainen JK, Niinemets Ü (2014) Plant volatiles in polluted atmospheres: stress responses and signal degradation. Plant Cell Environ 37:1892-1904

Bolan NS (1991) A critical review on the role of mycorrhizal fungi in the uptake of phosphorus by plants. Plant Soil 134:189-207

Box GEP, Cox DR (1964) An analysis of transformations. J R Stat Soc B 26:211-252

Braun S, Achermann B, De Marco A, Pleijel H, Karlsson PE, Rihm B, Schindler C, Paoletti E (2017) Epidemiological analysis of ozone and nitrogen impacts on vegetation-critical evaluation and recommendations. Sci Total Environ 603-604:785-792

Cailleret M, Ferretti M, Gessler A, Rigling A, Schaub M (2018) Ozone effects on European forest growth-towards an integrative approach. J Ecol 106:1377-1389

Calatayud V, Cerveró J, Sanz MJ (2007) Foliar, physiologial and growth responses of four maple species exposed to ozone. Water Air Soil Pollut 185:239-254

Chappelka AH, Grulke NE (2016) Disruption of the 'disease triangle' by chemical and physical environmental change. Plant Biol 18:5-12 
Cui L, Mu L (2016) Ectomycorrhizal communities associated with Tilia amurensis trees in natural versus urban forests of Heilongjiang in northeast China. J For Res 27:401-406

Dong X, Wang M, Ling N, Shen Q, Guo S (2016) Effects of iron and boron combinations on the suppression of Fusarium wilt in banana. Sci Rep 6:38944

Drüge U, Schonbeck F (1993) Effect of vesicular-arbuscular mycorrhizal infection on transpiration, photosynthesis and growth of flax (Linum usitatissimum L.) in relation to cytokinin levels. J Plant Physiol 141:40-48

Francini A, Nali C, Picchi V, Lorenzini G (2007) Metabolic changes in white clover clones exposed to ozone. Environ Exp Bot 60:11-19

Fuchen S, Tingfen Y, Yuangang Z (1998) Characteristics of reproductive biology for Larix originating in Japan. J For Res 9:51-53

Futai K, Taniguchi T, Kataoka R (2008) Ectomycorrhizae and their importance in forest ecosystems. Mycorrhizae: sustainable agriculture and forestry. Springer, Dordrecht, pp 241-285

Hoshika Y, Omasa K, Paoletti E (2013) Both ozone exposure and soil water stress are able to induce stomatal sluggishness. Environ Exp Bot 88:19-23

Jiang JF, Wan X, Li JG, Dong YH (2016) Effect of boron nutrition on resistance response of tomato against bacterial wilt caused by Ralstonia solanacearum. J Plant Pathol 98:117-122

Jiang-shan Z, Jian-fen G, Guang-shui C, Wei Q (2005) Soil microbial biomass and its controls. J For Res 16:327-330

Jolivet Y, Bagard M, Cabané M, Vaultier M-N, Gandin A, Afif D, Dizengremel P, Le Thiec D (2016) Deciphering the ozone-induced changes in cellular processes: a prerequisite for ozone risk assessment at the tree and forest levels. Ann For Sci 73:923-943

Karnosky DF, Pregitzer KS, Zak DR, Kubiske ME, Hendrey GR, Weinstein D, Nosal M, Percy KE (2005) Scaling ozone responses of forest trees to the ecosystem level in a changing climate. Plant Cell Environ 28:965-981

Koike T, Kitao M, Hikosaka K, Agathokleous E, Watanabe Y, Watanabe M, Eguchi N, Funada R (2018) Photosynthetic and photosynthesis-related responses of Japanese native trees to $\mathrm{CO}_{2}$ : results from phytotrons, open-top chambers, natural $\mathrm{CO}_{2}$ springs, and free-air $\mathrm{CO}_{2}$ enrichment. Springer, Cham, pp 425-449

Körner C (2006) Plant $\mathrm{CO}_{2}$ responses: an issue of definition, time and resource supply. New Phytol 172:393-411

Körner C (2009) Responses of humid tropical trees to rising $\mathrm{CO}_{2}$. Annu Rev Ecol Evol Syst 40:61-79

Lamichhane JR, Dürr C, Schwanck AA, Robin M-H, Sarthou J-P, Cellier V, Messéan A, Aubertot J-N (2017) Integrated management of damping-off diseases. A review. Agron Sustain Dev 37:10

Lefohn AS, Malley CS, Smith L, Wells B, Hazucha M, Simon H, Naik V, Mills G, Schultz MG, Paoletti E, De Marco A, Xu X, Zhang L, Wang T, Neufeld HS, Musselman RC, Tarasick D, Brauer M, Feng Z, Tang H, Kobayashi K, Sicard P, Solberg S, Gerosa G (2018) Tropospheric ozone assessment report: global ozone metrics for climate change, human health, and crop/ecosystem research. Elem Sci Anthr 6:28

Li T, Blande JD, Holopainen JK (2016) Atmospheric transformation of plant volatiles disrupts host plant finding. Sci Rep 6:33851

Li L, Wang X, Niu J, Cui J, Zhang Q, Wan W, Liu B (2017a) Effects of elevated atmospheric $\mathrm{O}_{3}$ concentrations on early and late leaf growth and elemental contents of Acer truncatum Bung under mild drought. Acta Ecol Sin 37:31-34

Li P, Feng Z, Catalayud V, Yuan X, Xu Y, Paoletti E (2017b) A metaanalysis on growth, physiological, and biochemical responses of woody species to ground-level ozone highlights the role of plant functional types. Plant Cell Environ 40:2369-2380

Li P, De Marco A, Feng Z, Anav A, Zhou D, Paoletti E (2018a) Nationwide ground-level ozone measurements in China suggest serious risks to forests. Environ Pollut 237:803-813
Li J, Wu G, Guo Q, Korpelainen H, Li C (2018b) Fast-growing Larix kaempferi suffers under nutrient imbalance caused by phosphorus fertilization in larch plantation soil. For Ecol Manag 417:49-62

Li K, Jacob DJ, Liao H, Shen L, Zhang Q, Bates KH (2019a) Anthropogenic drivers of 2013-2017 trends in summer surface ozone in China. Proc Natl Acad Sci USA 116:422-427

Li P, Zhou H, Xu Y, Shang B, Feng ZZ (2019b) The effects of elevated ozone on the accumulation and allocation of poplar biomass depend strongly on water and nitrogen availability. Sci Total Environ 665:929-936

Maathuis FJM (2014) Sodium in plants: perception, signalling, and regulation of sodium fluxes. J Exp Bot 65:849-858

Masaki T, Oguro M, Yamashita N, Otani T, Utsugi H, Utsugi H (2017) Reforestation following harvesting of conifer plantations in Japan: current issues from silvicultural and ecological perspectives. Reforesta 3:125

Nagashima T, Sudo K, Akimoto H, Kurokawa J, Ohara T (2017) Longterm change in the source contribution to surface ozone over Japan. Atmos Chem Phys 17:8231-8246

Nair PR, Ajayakumar RS, David LM, Girach IA, Mottungan K (2018) Decadal changes in surface ozone at the tropical station Thiruvananthapuram $\left(8.542^{\circ} \mathrm{N}, 76.858^{\circ} \mathrm{E}\right)$, India: effects of anthropogenic activities and meteorological variability. Environ Sci Pollut Res 25:14827-14843

Nopmongcol U, Alvarez Y, Jung J, Grant J, Kumar N, Yarwood G (2017) Source contributions to United States ozone and particulate matter over five decades from 1970 to 2020. Atmos Environ 167:116-128

Oksanen E (2018) Trichomes form an important first line of defence against adverse environment-new evidence for ozone stress mitigation. Plant Cell Environ 41:1497-1499

Paoletti E (2005) Ozone slows stomatal response to light and leaf wounding in a Mediterranean evergreen broadleaf, Arbutus unedo. Environ Pollut 134:439-445

Paoletti E, Grulke NE (2005) Does living in elevated $\mathrm{CO}_{2}$ ameliorate tree response to ozone? A review on stomatal responses. Environ Pollut 137:483-493

Ryu K, Watanabe M, Shibata H, Takagi K, Nomura M, Koike T (2009) Ecophysiological responses of the larch species in northern Japan to environmental changes as a basis for afforestation. Landsc Ecol Eng 5:99-106

Seseni L, Regnier T, Roux-van der Merwe MP, Mogale E, Badenhorst J (2015) Control of Fusarium spp. causing damping-off of pine seedlings by means of selected essential oils. Ind Crops Prod 76:329-332

Shang B, Feng Z, Li P, Calatayud V (2018) Elevated ozone affects C, $\mathrm{N}$ and $\mathrm{P}$ ecological stoichiometry and nutrient resorption of two poplar clones. Environ Pollut 234:136-144

Shang B, Yuan X, Li P, Xu Y, Feng Z (2019) Effects of elevated ozone and water deficit on poplar saplings: changes in carbon and nitrogen stocks and their allocation to different organs. For Ecol Manag 441:89-98

Sicard P, De Marco A, Troussier F, Renou C, Vas N, Paoletti E (2013) Decrease in surface ozone concentrations at Mediterranean remote sites and increase in the cities. Atmos Environ 79:705-715

Sicard P, Anav A, De Marco A, Paoletti E (2017) Projected global tropospheric ozone impacts on vegetation under different emission and climate scenarios. Atmos Chem Phys Discuss 17:12177-12196

Singh E, Tiwari S, Agrawal M (2009) Effects of elevated ozone on photosynthesis and stomatal conductance of two soybean varieties: a case study to assess impacts of one component of predicted global climate change. Plant Biol 11:101-108

Sugai T, Kam D-G, Agathokleous E, Watanabe M, Kita K, Koike $\mathrm{T}$ (2018) Growth and photosynthetic response of two larches 
exposed to $\mathrm{O}_{3}$ mixing ratios ranging from preindustrial to near future. Photosynthetica 56:901-910

Sugai T, Watanabe T, Kita K, Koike T (2019) Nitrogen loading increases the ozone sensitivity of larch seedlings with higher sensitivity to nitrogen loading. Sci Total Environ 663:587-595

Terrer C, Vicca S, Hungate BA, Phillips RP, Prentice IC (2016) Mycorrhizal association as a primary control of the $\mathrm{CO}_{2}$ fertilization effect. Science 353:72-74

Tjoelker MG, Volin JC, Oleksyn J, Reich PB (1995) Interaction of ozone pollution and light effects on photosynthesis in a forest canopy experiment. Plant Cell Environ 18:895-905

Torsethaugen G, Pell EJ, Assmann SM (1999) Ozone inhibits guard cell K+ channels implicated in stomatal opening. Proc Natl Acad Sci USA 96:13577-13582

van der Heijden MGA, Klironomos JN, Ursic M, Moutoglis P, Streitwolf-Engel R, Boller T, Wiemken A, Sanders IR (1998) Mycorrhizal fungal diversity determines plant biodiversity, ecosystem variability and productivity. Nature 396:69-72

Wang X, Qu L, Mao Q, Watanabe M, Hoshika Y, Koyama A, Kawaguchi K, Tamai Y, Koike T (2015) Ectomycorrhizal colonization and growth of the hybrid larch $\mathrm{F}_{1}$ under elevated $\mathrm{CO}_{2}$ and $\mathrm{O}_{3}$. Environ Pollut 197:116-126

Wang X, Agathokleous E, Qu L, Fujita S, Watanabe M, Tamai Y, Mao Q, Koyama A, Koike T (2018) Effects of simulated nitrogen deposition on ectomycorrhizae community structure in hybrid larch and its parents grown in volcanic ash soil: the role of phosphorous. Sci Total Environ 618:905-915
Watanabe M, Mao Q, Novriyanti E, Kita K, Takagi K, Satoh F, Koike $\mathrm{T}$ (2013) Elevated $\mathrm{CO}_{2}$ enhances the growth of hybrid larch $\mathrm{F}_{1}$ (Larix gmelinii var. japonica $x$ L-kaempferi) seedlings and changes its biomass allocation. Trees 27:1647-1655

Wittig VE, Ainsworth EA, Naidu SL, Karnosky DF, Long SP (2009) Quantifying the impact of current and future tropospheric ozone on tree biomass, growth, physiology and biochemistry: a quantitative meta-analysis. Glob Chang Biol 15:396-424

Yang AR, Hwang J, Cho MS, Son Y (2016) The effect of fertilization on early growth of konara oak and Japanese zelkova seedlings planted in a harvested pitch pine plantation. J For Res 27:863-870

Yang G, Wagg C, Veresoglou SD, Hempel S, Rillig MC (2018) How soil biota drive ecosystem stability. Trends Plant Sci 23:1057-1067

Yin D, Deng X, Song R (2016) Synergistic effects between Suilllus luteus and Trichoderma virens on growth of Korean spruce seedlings and drought resistance of Scotch pine seedlings. J For Res 27:193-201

Publisher's Note Springer Nature remains neutral with regard to jurisdictional claims in published maps and institutional affiliations. 